Florida International University

FIU Digital Commons

3-31-2011

\title{
Water Resources Assessment and Geographic Information System (GIS)-based Stormwater Runoff Estimates for Artificial Recharge of Freshwater Aquifers in New Providence, Bahamas
}

Mildred Genevieve Diamond

Florida International University, diamondg@fiu.edu

DOI: $10.25148 /$ etd.FI1 1050903

Follow this and additional works at: https://digitalcommons.fiu.edu/etd

\section{Recommended Citation}

Diamond, Mildred Genevieve, "Water Resources Assessment and Geographic Information System (GIS)-based Stormwater Runoff Estimates for Artificial Recharge of Freshwater Aquifers in New Providence, Bahamas" (2011). FIU Electronic Theses and Dissertations. 396.

https://digitalcommons.fiu.edu/etd/396

This work is brought to you for free and open access by the University Graduate School at FIU Digital Commons. It has been accepted for inclusion in FIU Electronic Theses and Dissertations by an authorized administrator of FIU Digital Commons. For more information, please contact dcc@fiu.edu. 


\title{
FLORIDA INTERNATIONAL UNIVERSITY \\ Miami, Florida
}

\begin{abstract}
WATER RESOURCES ASSESSMENT AND GEOGRAPHIC INFORMATION SYSTEM (GIS)-BASED STORMWATER RUNOFF ESTIMATES FOR ARTIFICIAL RECHARGE OF FRESHWATER AQUIFERS IN NEW PROVIDENCE, BAHAMAS
\end{abstract}

\author{
A thesis submitted in partial fulfillment of the \\ requirements for the degree of \\ MASTER OF SCIENCE \\ in \\ ENVIRONMENTAL STUDIES \\ by \\ Mildred Genevieve Diamond
}

2011 


\section{To: Dean Kenneth Furton}

College of Arts and Sciences

This thesis, written by Mildred Genevieve Diamond, and entitled Water Resources Assessment and Geographic Information System (GIS)-based Stormwater Runoff Estimates for Artificial Recharge of Freshwater Aquifers in New Providence, Bahamas, having been approved in respect to style and intellectual content, is referred to you for judgment.

We have read this thesis and recommend that it be approved.

Mahadev Bhat

Jeffrey A. Onsted

Daniel Gann

Assefa M. Melesse, Major Professor

Date of Defense: March 31, 2011

The thesis of Mildred Genevieve Diamond is approved.

\begin{tabular}{r}
$\begin{array}{r}\text { Dean Kenneth Furton } \\
\text { College of Arts and Sciences }\end{array}$ \\
\hline Interim Dean Kevin O'Shea \\
University Graduate School
\end{tabular}

Florida International University, 2011 


\section{DEDICATION}

My prayers were answered beyond all expectation and this work belongs to God, to whom it is dedicated.

I dedicate it also to my children, Kimberley, Julie, Alexis, Douglas, and Drew, who have become my advisors during this journey, and to my grandchildren, Zachary, Julia, Mac, and Judah. May you find adventure around every bend.

Finally, it is dedicated to my siblings, Tony, Shirley, and Paul, who are an endless source of encouragement. 


\section{ACKNOWLEDGMENTS}

Many thanks to my major professor, Dr. Assefa Melesse, for his continuing encouragement and for helping me attain my goal. Thanks to Dr. Mahadev Bhat, Dr. Jeffrey Onsted and Mr. Daniel Gann for their valuable comments and suggestions. Special thanks to Dr. Richard Cant who provided me with an understanding of the issues

facing the Bahamas. I must also thank Mr. John Knowles of The Nature Conservancy who provided me with necessary GIS data for use in this analysis. Finally I am indebted to Mr. Gordon England of Stormwater Solutions, Inc. who provided the key GIS data, without which this analysis would have hardly been possible. 


\begin{abstract}
OF THE THESIS
WATER RESOURCES ASSESSMENT AND GEOGRAPHIC INFORMATION

SYSTEM (GIS)-BASED STORMWATER RUNOFF ESTIMATES FOR ARTIFICIAL RECHARGE OF FRESHWATER AQUIFERS IN NEW PROVIDENCE, BAHAMAS
\end{abstract}

by

Mildred Genevieve Diamond

Florida International University, 2011

Miami, Florida

Professor Assefa M. Melesse, Major Professor

The Bahamas is a small island nation that is dealing with the problem of freshwater shortage. All of the country's freshwater is contained in shallow lens aquifers that are recharged solely by rainfall. The country has been struggling to meet the water demands by employing a combination of over-pumping of aquifers, transport of water by barge between islands, and desalination of sea water. In recent decades, new development on New Providence, where the capital city of Nassau is located, has created a large area of impervious surfaces and thereby a substantial amount of runoff with the result that several of the aquifers are not being recharged. A geodatabase was assembled to assess and estimate the quantity of runoff from these impervious surfaces and potential recharge locations were identified using a combination of Geographic Information Systems (GIS) and remote sensing. This study showed that runoff from impervious surfaces in New Providence represents a large freshwater resource that could potentially be used to recharge the lens aquifers on New Providence. 


\section{TABLE OF CONTENTS}

CHAPTER

PAGE

1.0. INTRODUCTION

1.1. Overview - Accessibility to freshwater 1

1.2. Sources of freshwater 5

1.3. Water issues in the Caribbean and Bahamas 6

1.4. Freshwater in New Providence 7

1.5. Questions to be addressed by this study 8

1.6. Objectives of this study 8

1.7. Significance of this study 9

2.0. LITERATURE REVIEW 10

2.1. Overview of groundwater 10

2.2. Background of artificial recharge 11

2.3. Proven benefits of artificial recharge 12

2.4. Methods of artificial recharge 14

2.5. Recent innovations 15

2.6. Technologies in use in the Caribbean region 16

2.7. Use of GIS to select sites for artificial recharge 17

3.0. DESCRIPTION OF STUDY AREA 18

3.1. The Bahama Islands 18

3.2. Climate and vegetation 19

3.3. Geology 20

3.4. New Providence island 22

$\begin{array}{ll}3.5 . & 27 \\ 3.6 . & \end{array}$

3.6. Other water related issues 32

4.0. METHODS 34

4.1. GIS and runoff calculation $\quad 34$

4.2. Suitable recharge areas 36

4.3. Data used 36

4.4. Preparation of data 37

4.5. GIS data preparation 38

4.6. Selection of recharge locations 43

4.7. Curve numbers 44

4.8. Weighted curve number 44

5.0. $\quad$ RESULTS AND DISCUSSION 47

5.1. GIS maps and calculation $\quad 47$

5.2. GIS runoff depth $\quad 47$

5.3. GIS runoff volume 48

5.4. Suitable recharge locations 49 
6.0. CONCLUSIONS AND RECOMMENDATIONS

6.1. Conclusions

6.2. Recommendations

6.3. Future Research

REFERENCES

APPENDICES 


\section{LIST OF TABLES}

TABLE

PAGE

Table 1-1. Estimate of global water available (Source: Shiklomanov, 1993)

Table 3-1. Population distribution of the Bahamas (Source: Bahamas Dept. of Statistics)

Table 3-2. Capacity of aquifers on New Providence Island (Source: Cant and Weech, 1980)

Table 3-3. New Providence freshwater production from all sources -2004 to 2008 (Source: Bahamas Water \& Sewerage Corp.)

Table 6-1. Runoff volume results 


\section{LIST OF FIGURES}

FIGURE

PAGE

Figure 1.1. Global water scarcity (Source: Westcoat \& White, 2008)

4

Figure 3.1. Illustration of Ghyben-Hertzberg lens aquifer found in the Bahamas (Source: Roebuck, 2004)

Figure 3.2. New Providence elevation map

Figure 3.3. Rainfall average totals for N.P. 1971-2000 (Source: Bahamas Meteorological Office)

Figure 3.4. Monthly average rainfall totals for NP 1971-2000 (Source: Bahamas Meteorological Office)

Figure 3.5. Yearly maximum and minimum temperatures 1971-2000 (Source: Bahamas Meteorological Office)

Figure 3.6. Population on New Providence (N.P.) 1975 to 2000

(Source: Bahamas Office of Statistics)

Figure 3.7. Water usage 1975 to 2003 in imperial gallons (IG)

(Source: Bahamas Water \& Sewerage Corp.)

Figure 3.8. Groundwater production in imperial gallons (IG)

(Source: Bahamas Water \& Sewerage Corp.)

Figure 3.9. Freshwater production by reverse osmosis, purchase, and import from Andros (Source: Bahamas Water \& Sewerage Corp.)

Figure 4.1. Human altered lands extracted from N.P. land cover layer

Figure 4.2. Roads and zoning plots corresponding with human altered areas extracted

Figure 4.3. Aerial images overlay roads and plots for data extraction

Figure 4.4. Selection of plots using aerial image

Figure 4.5. Slope percent derived from digital elevation model

Figure 4.6. Tree to selection of curve numbers 
Figure 5.1. Average runoff depth in meters based on average rainfall 1971-2000

Figure 5.2. Suitable recharge locations

Figure 5.3. Drainage wells in city of Nassau (Source: Bahamas Ministry of Works and Transportation, 2010) 


\section{LIST OF ABBREVIATIONS AND ACRONYMS}

AOI - Area of Interest

ARC - Antecedent Runoff Condition

ASR - Aquifer Storage and Retrieval

BEST - Bahamas Environmental Science and Technology Commission

BWSC - Bahamas Water and Sewerage Corporation

CERP - Comprehensive Everglades Restoration Plan

DEM - Digital Elevation Model

DOS - Department of Statistics of the Bahamas

ERDAS - Earth Resources Data Analysis System

ESRI - Environmental Systems Research Institute

FAO - Food and Agriculture Organization

FIS - Fractional Impervious Surface

GIS - Geographic Information System

GLOVIS - Global Visualization

HSG - Hydrologic Soil Group

NAD - North American Datum

NDVI - Normalized Difference Vegetation Index

NP - New Providence

NRCS - Natural Resources Conservation Service

OAS - Organization of American States

SFWMD - South Florida Water Management District

SRTM - Shuttle Radar Topography Mission 
SSI - Stormwater Solutions Incorporated

TIFF - Tagged Image File Format

TNC - The Nature Conservancy

TR-55 - Technical Report 55

USACE - United States Army Corps of Engineers

USDA - United States Department of Agriculture

USFWS - United States Fish and Wildlife Service

USGS - United States Geological Survey

UTM - Universal Transverse Mercator 


\subsection{INTRODUCTION}

Fresh liquid water is one of the resources required by every living organism on this planet, yet a sizable percentage of the earth's people do not have access to an adequate supply. These people live in unsanitary conditions where day to day survival is their main concern. They are subject to famine as a result of food shortages and inability to grow food, and to illness related to unclean water and diseases borne by it. While most of these people live in the developing world, the problem of water shortage is becoming more widespread even in the developed world, and nations that currently enjoy a fairly high standard of living are facing a future where access to fresh water will be more costly and difficult (Rosegrant, Cai, and Cline, 2002).

\subsection{Overview - Accessibility to freshwater}

The availability of freshwater for domestic, agricultural and industrial uses is one of the most serious issues facing much of the world today. The Millennium Ecosystem Assessment found that more than one billion people live in areas that do not have sustainable freshwater supplies, and are meeting their needs through overdraft or engineered transfers of water (Millennium Ecosystem Assessment, 2005). Freshwater is a vital resource, since life cannot be sustained without it. The trend in overuse of existing freshwater reserves is alarming and countries need to address it in their long range planning.

The supply of freshwater is distributed unevenly across the planet, and is governed by factors such as geomorphology, geology, climate, and location. The use of freshwater varies among countries in the developed and developing world. While we tend to view 
freshwater as freely available and renewable, in fact the time required for liquid water to move among the various storage areas of the planet, the oceans, rivers, aquifers, lakes, and atmosphere, can exceed a human lifetime. It is therefore vital that this resource be carefully managed.

While clean freshwater resources on the planet become more scarce, it is being recognized generally that nations must develop integrated water resource management plans to ensure that there will be sufficient freshwater for use by all peoples today and for future generations (Rosegrant, Cai, \& Cline, 2002). These plans must encompass all phases of water management and must acknowledge and accommodate the various sectors of water use: social (human), economic, and environmental (Rosegrant, Cai, \& Cline, 2002). .

The use of all environmental resources is shared among the three sectors - social or human, economic and environmental, and each must be considered in the management of these resources. Potable fresh water is in high demand across the globe and the nature of its uneven distribution presents unique problems in its management (Westcoat \& White, 2008). Fresh water is one of the requirements for humans to live and maintain sanitary conditions that are conducive to good health. Human bodies are made up mostly of water (seventy percent) and must have drinking water daily to survive. In addition, access to sources of clean fresh water is vital to maintain sanitary living conditions and to prevent illness from water borne diseases. Furthermore, in order to maintain food supplies, fresh water is needed for irrigation of crops. Many ecosystem components require a reliable supply of fresh water to function properly and this has been seen to bring about conflict between human needs and the environment (Rosegrant, Cai, \& Cline, 2002). It is often 
difficult to maintain a balance between the needs of farmers for water to irrigate crops and the needs of a river to maintain a healthy riparian population (Millennium Ecosystem Assessment, 2005). It is difficult to overestimate the economic value of water as it is a vital component in almost every undertaking of industry, agriculture, and recreation. In fact, as freshwater becomes scarcer, it becomes more of an economic good in itself as nations are forced to find alternate means of obtaining freshwater supplies. Desalination is one such method that is expensive both in the cost of obtaining the water and in disposal of the waste generated. Engineered transfer of water is another, which can involve construction of pipelines, shipping by barge, as well as bottling and shipping of water by major corporations. The projected future cost of providing clean freshwater for all sectors has been estimated to total $\$ 16$ trillion in the period from 2008 to 2025 (Hoffman, 2009). 


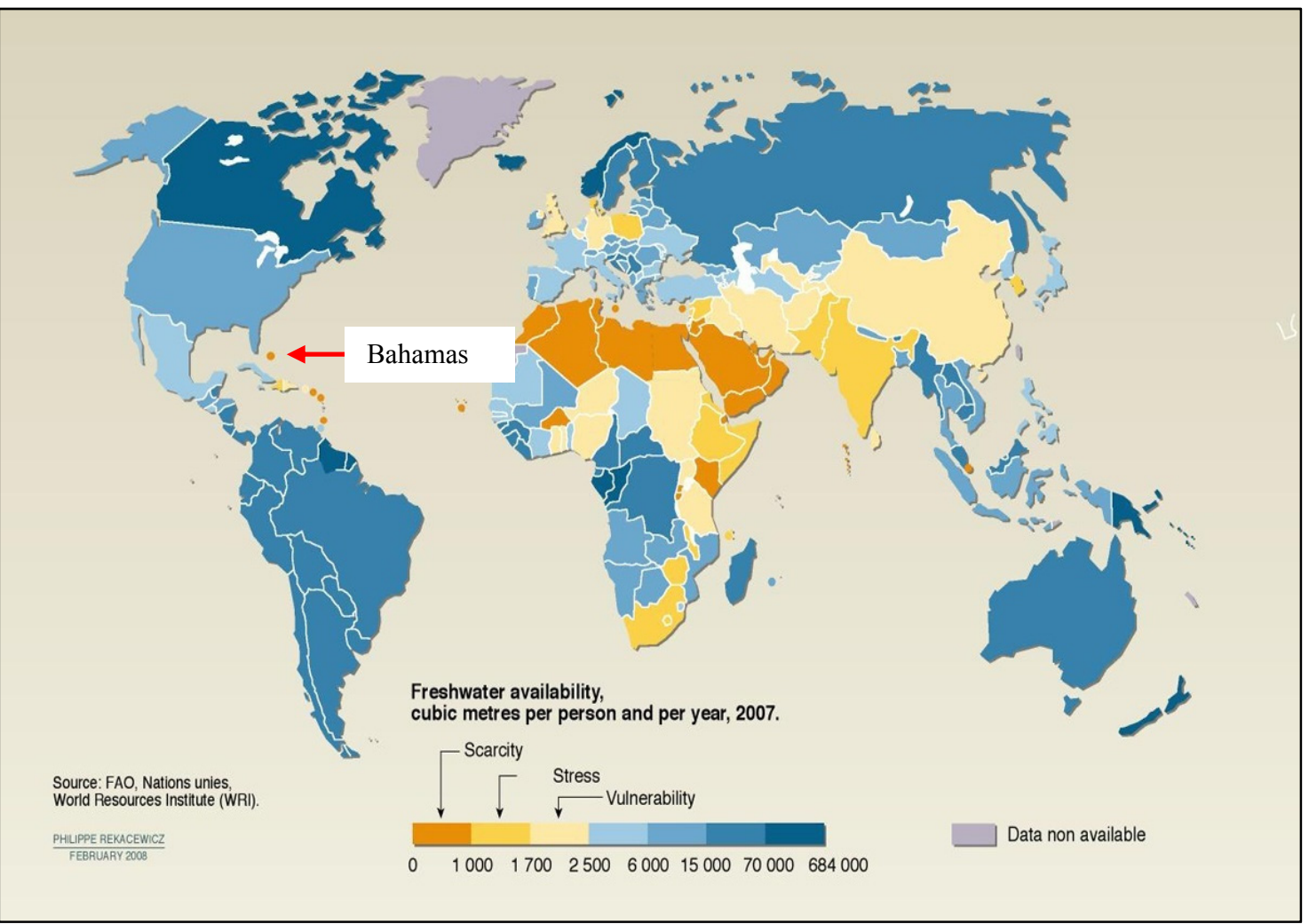

Figure 1.1.Global water scarcity. (Source: Westcoat \& White 2008)

Although developed nations tend to value water low on the scale of economic goods, it is, in fact, one of the Earth's most valuable resources. Furthermore, nations are prepared to invest large sums into development of technologies to aid in providing freshwater to their populations. The Bahamas, as an example, currently pays $\$ 6.60$ for every thousand imperial gallons of freshwater produced by reverse osmosis (Stuart, 2009). The produced water is delivered mostly to residences where it is used for drinking as well as for every other household need, including flushing of toilets, watering lawns, and washing automobiles. The true costs of providing clean water are often never calculated and governments are put in the position of subsidizing water supplies. 


\subsection{Sources of freshwater}

Surface water - lakes, rivers, streams - for most of the history of human life on this planet, has been the main source of water for communities. For the last century, groundwater has steadily replaced surface water in this capacity. Most of the liquid freshwater on the planet is stored as groundwater in aquifers beneath the surface of the earth. It has been estimated that as much as $97 \%$ of available freshwater is stored in this manner as shown in Table 1.1 (Shiklomanov, 1993).

Table 1.1.Estimate of global water available (Source: Shiklomanov, 1993)

\begin{tabular}{|l|l|l|l|}
\hline Water source & $\begin{array}{l}\text { Water volume } \\
\text { in cubic miles }\end{array}$ & $\begin{array}{l}\text { Water volume in } \\
\text { cubic kilometers }\end{array}$ & $\begin{array}{l}\text { Percent of } \\
\text { freshwater }\end{array}$ \\
\hline & & & \\
\hline $\begin{array}{l}\text { Oceans, Seas, \& } \\
\text { Bays }\end{array}$ & $321,000,000$ & $1,338,000,000$ &.. \\
\hline $\begin{array}{l}\text { Ice Caps, Glaciers, \& } \\
\text { Permanent Snow }\end{array}$ & $5,773,000$ & $24,064,000$ & 68.6 \\
\hline Ground Water & $5,624,000$ & $23,400,000$ &.. \\
\hline Fresh & $2,526,000$ & $10,530,000$ & 30.1 \\
\hline Saline & $3,088,000$ & $12,870,000$ &.. \\
\hline Soil Moisture Ice and & 3,959 & 16,500 & 0.05 \\
\hline $\begin{array}{l}\text { Ground } \\
\text { Permafrost }\end{array}$ & 71,970 & 300,000 & 0.86 \\
\hline Lakes & 42,320 & 176,400 &.. \\
\hline Fresh & 21,830 & 91,000 & 0.26 \\
\hline Saline & 20,490 & 85,400 &.. \\
\hline Atmosphere & 3,095 & 12,900 & 0.04 \\
\hline Swamp Water & 2,752 & 11,470 & 0.03 \\
\hline Rivers & 509 & 2,120 & 0.006 \\
\hline Biological Water & 269 & 1,120 & 0.003 \\
\hline
\end{tabular}

Natural recharge to aquifers occurs when water from rivers, streams, and rainfall sinks into the ground and travels through cracks and pores in the subsurface to reach the storage areas (Bowen, 1980). This recharge process not only captures freshwater for storage but also filters out impurities, thereby providing clean water for future use that is 
generally not subject to evaporation (Bowen, 1980). In modern times, disruptions of these natural recharge methods, in addition to over-pumping of aquifers, have led to declines in groundwater resources in many areas. Rivers and streams have been dammed and diverted to create surface reservoirs for use in cities and agricultural areas or for creation of hydroelectric power (Rosegrant, Cai, \& Cline, 2002). Many developed areas have been paved over in the process of city and road building, creating impervious surfaces that prevent rainfall from seeping into the ground, thereby causing the loss of this resource and often causing serious flooding of inhabited places.

As a result of these losses, in conjunction with increased use, nations are finding it necessary to find alternate methods of producing freshwater to meet the needs of their populations. One such method is desalination - the removal of salt from sea water to produce fresh - which is used in many areas. While this technology does supplement natural supplies of freshwater, it does so at a large cost in energy and waste that must be disposed of in the environment. Dependency on these kinds of technologies will become more costly and tenuous as the world's supply of fossil fuels dwindles, unless alternative methods and fuels are developed.

\subsection{Water issues in the Caribbean and Bahamas}

Small island developing states such as the Bahamas will be affected by global issues like climate change: more frequent droughts and seawater intrusion caused by hurricanes. For these nations it is imperative to find solutions to freshwater shortages that they will, no doubt, face in the future. The United Nations has determined that the Bahamas and 
much of the Caribbean region are facing water stress or scarcity in the near future as shown in Figure 1.1 (Westcoat \& White, 2008).

\subsection{Freshwater in New Providence}

In the Bahama Island of New Providence all natural freshwater stored as groundwater comes from rain but much of the island has been converted to impervious surface by development and road building. Altered land use has resulted in increased flooding in residential and business areas and a huge loss of water that is being wasted as government directs its resources and attention to removing it from the island as quickly as possible, which is being done by directing it to the ocean via drains, or by deep injection below the surface.

New Providence has been depending on imports from the North Andros aquifer, 40 miles away, for the last three decades (Stuart, 2009). The North Andros aquifer is at high risk of salt intrusion as sea level rises. Plans for securing freshwater in the future mainly focus on desalination by reverse osmosis (RO). Government intends to produce by RO most of the freshwater needed by 2012 (BWSC). As fuel costs rise, water will become more expensive since the Bahamas has no natural energy resources available and depends on imports. The technology of reverse osmosis is generally suitable for areas that are rich in cheap fuel (Einav et al, 2002) and it is not a practical solution for New Providence.

Much of the freshwater use on New Providence is for tourism, which is the main source of income for the island as well as the nation. Should this industry weaken or fail, water use will drop, but it will be difficult for government to continue subsidizing production by R.O. or other artificial means as a result of reduced income. If all aquifers 
were healthy and operational, it would represent a large resource for the residents. However, at this time, several of the aquifers have become saline and will require years of remediation to restore them to usefulness. This is where a coordinated and carefully implemented artificial recharge plan can be most beneficial, so that all aquifers can be restored to usefulness and health by the long-term addition of freshwater from rain. If tourism continues in its present role as the largest component of the economy, the present rate of freshwater use will continue or increase, with concurrent increase in both financial and environmental costs.

1.5. Questions to be addressed by this study

1. What factors in the hydrogeology of the island of New Providence will influence the effectiveness of rainwater harvesting for artificial recharge?

2. What areas of the landscape are likely to have the most potential for artificial recharge?

3. How much rainwater is it possible to capture by the proven methods of artificial recharge?

1.6. Objectives of this study

The specific objectives of this study are to

1. determine the quantity of rainwater that can be captured for recharge and

2. select potential areas based on presence of impervious surfaces capable of producing runoff. 


\subsection{Significance of this Study}

In spite of the problems that New Providence is facing with water scarcity, flooding, and possible environmental impacts from disposal of storm water runoff and waste from reverse osmosis operations, no analysis has been done to quantify the runoff on impervious surfaces created by development. Yet, given the abundance of rainfall received on this island, it would be expected that this water represents a valuable resource for the population. The purpose of this study is to assess the extent of this resource and illustrate the possibility and practicality of capturing it by artificial recharge. 


\subsection{LITERATURE REVIEW}

Much has been written on the topic of artificial recharge of groundwater aquifers, as this technology has become ever more important to the many nations facing water shortages in the near future. This chapter will provide a review of the types of artificial recharge methods in use and of studies done in various parts of the world that demonstrate the effectiveness of this technology as well as the applicability of geographic information systems (GIS) in the assessment of groundwater recharge.

\subsection{Overview of groundwater}

Most of the readily available freshwater on earth, that is, water in liquid form, is contained in natural subsurface storage areas called groundwater aquifers. It has been estimated that as much as ninety-seven percent of all liquid freshwater on the planet is stored in these aquifers (Shiklomanov, 1993). The use of groundwater for all purposes has been steadily increasing over the last century as a result of a number of causes, mainly overuse of surface water that has led to the decline of this resource (Brown, 2006). As the population of the earth increased, the need to increase production of food led to increased use of water for irrigation of crops, the leading cause of depletion of surface water and increase of groundwater use (Brown, 2006). Today about seventy percent of all fresh water use is for irrigation of crops (Rosegrant et al, 2002).

The over-pumping of freshwater from aquifers coupled with the increased areas of impervious surfaces such as roads, parking lots, buildings, and other built structures has led to decreasing levels of groundwater worldwide. Pyne (1995) reported on a number of nations where this combination of factors had seriously affected the groundwater level. 
In Saudi Arabia ninety-seven percent of all water used was groundwater and the levels of aquifers were declining so rapidly that it was predicted they would last only another twenty to fifty years. Many aquifers in India and China had already gone dry, while in the Denver Basin of Colorado the water level, previously close to the surface, had dropped to about 275 meters below the surface (Pyne, 1995). A confined aquifer that had provided freshwater to the Chicago, Illinois metropolitan area for over 100 years saw a decline in level of $60-240$ meters by the 1980s (Wescoat \& White, 2003). In Australia, excessive pumping of the shallow freshwater aquifers in the Eastern Coastal areas led to seawater intrusion in some of the coastal aquifers (Symposium, 1989) while in Pajaro Valley, California, sea water intrusion extended about one mile inland by the mid-1970s (O'Hare et al., 1986). The draining of wetlands for development is another cause of aquifer decline and of increased storm water runoff leading to flooding in urban areas (Pyne, 1995).

\subsection{Background of artificial recharge}

Artificial recharge of groundwater aquifers refers to any type of system designed for the purpose of directing water from the surface into natural subsurface storage areas. A number of methods exist and have been used successfully in various regions of the world. Artificial recharge can be accomplished by a variety of methods including spreading basins and rerouting of river waters, dams, bank infiltration, open wells and shafts, and roof-top rainwater harvesting. Artificial recharge has been practiced for a variety of reasons, which include water storage for future use, improvement of water quality by filtering through natural substances, prevention of sea water intrusion in coastal areas, 
reduction of flooding resulting from storm water runoff, and prevention of land subsidence due to over-pumping (Gale et al., 2002).

The technology of artificial recharge has been in use for centuries in some parts of the world. In India, methods such as check dams and storage ponds for runoff were constructed as early as $3000 \mathrm{BC}$ in rural areas where water scarcity was a problem (Gale, 2005). It was used in Europe as early as 1897 when the first project was begun in Sweden with the construction of a spreading basin at Goteborg to move water from rivers and streams to storage in underground aquifers (Bowen, 1980). In the Netherlands spreading basins have been used for years to deliver water from the Rhine River and the River Meuse to storage in aquifers within fine sand (Pyne, 1995).

These methods have been used both to provide a supply of usable water and to prevent seawater intrusion to the aquifers. In the United States, by the mid-twentieth century, the state of California was storing up to 375 million gallons of surface water daily by artificial recharge to underground aquifers (Bowen, 1980). In Orange County, California, hydraulic barriers to prevent sea water intrusion have been in use since 1976 in both confined and unconfined aquifers, and have demonstrated the additional benefit of recharging the groundwater as well as protecting that important resource (National Research, 2008).

\subsection{Proven benefits of artificial recharge}

It has been shown that artificial recharge of groundwater aquifers can provide a number of benefits to water users including the creation of a dependable source of fresh water for domestic, industrial, and agricultural use (Asano, 1985; Bowen, 1980) and disposal of storm water in urban areas (California Department of Water Resources, 
2009). Coastal sand dunes in municipalities such as Amsterdam, The Hague, and Leiden in The Netherlands have used artificial recharge methods to protect freshwater storage aquifers formed in coastal sand dunes from sea water intrusion. Such coastal sand dunes naturally retain rainwater, but over pumping of the aquifers can induce upwelling of the saline water that underlies the fresh (Bowen, 1980). Artificial recharge of such aquifers is effective both in preventing contamination by salt water and in providing high quality fresh water for municipal use.

For a century beginning in 1853 the city of Amsterdam in The Netherlands received a steady supply of fresh water from the coastal sand aquifer thirty kilometers away and by the 1950s the aquifer was in danger of being destroyed by sea water intrusion. A plan to prevent this intrusion and thus maintain the supply of fresh water for the city was put into effect. Beginning in 1956, water was diverted from the Rhine River, purified, and pumped fifty-five kilometers to recharge the dune aquifers. Since that time, this artificially recharged aquifer has continued as the main source of fresh water for Amsterdam, reliably supplying about seventy-five percent of its drinking water (Symposium, 1998).

From the late 1800s a large alluvial aquifer with artesian characteristics supplied the agricultural area of the Oxnard Plain in Central California in the United States with fresh water for domestic use and irrigation. By the 1940s the aquifer water level had dropped significantly and was fluctuating with changes in tides. By the 1950s sea water intrusion made many wells near the coast unusable because of high salinity levels. A number of projects starting in 1955 were initiated to recharge the aquifer via spreading basins. Over the years a combination of conservation, introduction of highly efficient irrigation 
methods and diversion of river water to recharge the aquifer brought about a rise in the water levels as well as a decrease in chloride content from $600 \mathrm{mg} / \mathrm{L}$ to less than $100 \mathrm{mg} / \mathrm{L}$ in 1997 (Symposium, 1998). By 1993, these combined efforts, along with increased availability of water for recharge from the Santa Clara River, saw a rise in the Oxnard and Mugu aquifers to above sea level (Izbicki, 1996).

In Paris, France, artificial recharge has been in use for more than thirty-five years to sustain the water supply in the city's overdrawn alluvial aquifers by drawing water from the Seine River, pre-treating it, and sending it to infiltration basins. Artificial recharge has proved to be an invaluable tool for managing both water quantity and quality. In two of the aquifers, Flins Aubergenville and Croissy sur Seine, the process of infiltration has been shown to remove high ammonia concentration from the water thus preventing a buildup of this chemical in the aquifers (Symposium, 1998). Stiefel (2007) showed improvement in water quality in a number of aquifers in the Wakal River Basin as a result of artificial recharge. Levels of chloride, sulfate, fluoride, calcium and magnesium hardness, dissolved solids, and turbidity were shown to be lower in those aquifers where artificial recharge was received (Stiefel 2007).

\subsection{Methods of artificial recharge}

Artificial recharge of groundwater aquifers is carried out by a number of methods. These can be generally described as direct surface, direct subsurface and indirect methods (Asano, 1985). Direct surface methods include surface spreading by flooding or diverting streams, by constructing spreading basins for rainfall runoff, and by using methods such as ridge and furrow irrigation for recharge of irrigation waters. Direct subsurface 
methods include injecting water into the aquifer by means of injection wells. Direct surface recharge can be accomplished by constructing dams and weirs to reroute rivers and streams to areas of recharge such as those used in The Netherlands as described by Peters (1998), where water from the Rhine and Meuse Rivers is redirected to basin recharge sites in coastal sand dunes. These basins have the added advantage of acting as a means for helping to clean the water of silt and impurities as it seeps through the sand and gravel before it enters the saturated zone. In 1996, the city of Surprise, Arizona, in the United States initiated a recharge project for the purpose of replenishing the local aquifer. An area of one hundred to three hundred acres was flooded to create a shallow wetland that would also serve as a recreational area for the community (Dagostino, 1996).

Indirect methods of artificial recharge include the practice of induced recharge in which water is induced to enter the aquifer from a stream bed by pumping the water out at a location a suitable distance from the well thus "inducing" water to enter the aquifer from above to replace the water removed by the pump. Other indirect methods include aquifer modifications such as bore blasting, and groundwater conservation structures such as dams and sealing of fractures in the aquifer (Bouwer, 2002).

\subsection{Recent innovations}

Aquifer storage and retrieval (ASR) is a fairly recent innovation in artificial recharge technology (Pyne, 1995). In this method, existing retrieval wells are used to deliver harvested water to an aquifer for storage and later retrieval (Pyne, 1995). The United States Army Corps of Engineers (USACE) along with the U.S. Fish and Wildlife 
Service (USFWS), and South Florida Water Management District (SFWMD), as part of the ongoing Comprehensive Everglades Restoration Plan (CERP), have implemented four ASR pilot projects in the South Florida region of the Everglades to determine the technical issues involved in this method of artificial recharge within the scope of the CERP. The ultimate goal is to implement a system to include 333 ASR wells, which will be the largest to date (Brown et al, 2005).

\subsection{Technologies in use in the Caribbean region}

The OAS Sourcebook (1997) lists a number of nations in the Latin America and Caribbean region that employ various methods of artificial recharge for the purpose of storing surface water for future use as well as for harvesting rainwater and re-use of reclaimed wastewater. These include infiltration basins, canals, and drainage wells for surface runoff. In the San Juan River basin in Argentina, artificial recharge was successfully accomplished using a combination of infiltration basins and canals to recharge the groundwater aquifer in the Valley of Tulum. In Barbados the limestone aquifer is recharged by way of drainage wells called suckwells. These wells are dug into the rock until an adequate fissure is reached through which the water is "sucked" into the subsurface. The suckwells are fed by runoff from road surfaces. The Barbados aquifer is also recharged by effluent from septic tank soakaways. Jamaica conserves excess runoff from road surfaces by treating it for settling of suspended solids in areas upgradient of sinkholes through which the water is directed to the karstic limestone aquifers. Jamaica recorded total recharge of four million cubic meters over eighteen months during which time some wells showed marked decrease in salinity levels (OAS, 1997). 


\subsection{Use of GIS to select sites for artificial recharge facilities}

Selecting suitable sites for recharge is vital to the success of the operation. The technology of GIS has been used successfully in selecting sites for effective artificial recharge. Using various digital layers, such as land use and cover, soil type and depth, geology, and others it is possible to pinpoint locations where recharge will be successful. Jothiprakash et al. (2003) used GIS in Tamilnadu, India to delineate potential zones for artificial recharge when it was found that existing recharge ponds were not effective due to the presence of large quantities of clay in the areas, which seriously reduces the percolation capacity of the soil. Using map layers such as permeability, soil depth and geology, the authors were able to pinpoint more suitable areas for recharge sites. Biswas (2008) demonstrated that GIS was an effective tool for siting of recharge areas in the Wakal River basin, India, and Ghayoumian et al. (2007) made use of GIS methods to determine the best recharge areas in a coastal aquifer in southern Iran with layers depicting land use, geomorphology, slope, infiltration rates, depth to groundwater, and soil permeability. In this latter study, the purpose of artificial recharge was to improve the quality of groundwater in the coastal aquifer, which was vulnerable to salt water intrusion. 


\subsection{DESCRIPTION OF STUDY AREA}

A general description of the Bahama Island archipelago is provided in this chapter along with a detailed description of the physical characteristics of the study island of New Providence. This description includes the use and production of fresh water from all sources.

\subsection{The Bahama Islands}

The Bahama Islands are part of an archipelago that stretches from $21^{\circ} \mathrm{N}$ to $27^{\circ} 30^{\prime} \mathrm{N}$ latitude and $69^{\circ}$ to $80^{\circ} 30^{\prime} \mathrm{W}$ longitude, which includes the Turks and Caicos Islands at the southern extreme (Carew \& Mylroie, 1997). The Bahamas consists of 19 populated islands (Dept. of Statistics, 2000) and hundreds of small cays and rocks, with total land area of 13,934 $\mathrm{km}^{2}(\mathrm{BEST}, 2005)$. The entire archipelago covers a total area of 300,000 $\mathrm{km}^{2}$ and stretches over $1,000 \mathrm{~km}$. The Bahama Islands comprise most of this area (Carew \& Mylroie, 1997). The population of the nation is small, totaling just over 300,000 , but this number is swelled by the roughly four million tourists who visit the country each year (Bahamas Handbook, 2010). About two-thirds of the population resides in Nassau, the nation's capital, on the island of New Providence (Dept. of Statistics, 2000). Table 3.1 shows the distribution of the population in 2000 and 2010.

The Bahama Platform is made up of a number of carbonate banks that are thick and covered with shallow water generally less than 10 meters deep over most of their area and separated by deep water channels (Carew \& Mylroie, 1997). The Bahama Islands are low lying with eolian ridges that were deposited by wind and waves during periods of high sea level, and lowlands of marine and terrestrial deposits (Carew \& Mylroie, 1997). 
Table 3-1. Population distribution of the Bahamas (Source: Bahamas Dept. of Statistics)

\begin{tabular}{|c|c|c|c|c|}
\hline \multicolumn{5}{|c|}{$\begin{array}{l}\text { PERCENTAGE DISTRIBUTION OF POPULATION BY ISLAND } \\
2000 \text { AND } 2010 \text { CENSUSES }\end{array}$} \\
\hline \multirow[b]{2}{*}{ ISLAND } & \multicolumn{2}{|c|}{2000} & \multicolumn{2}{|c|}{2010} \\
\hline & POPULATION & PERCENTAGE & POPULATION & $\begin{array}{l}\text { PERCENTAGE } \\
\text { DISTRIBUTION }\end{array}$ \\
\hline ALL BAHAMAS & 303,611 & 100 & 353,658 & 100 \\
\hline NEW PROVIDENCE & 210,832 & 69.44 & 248,948 & 70.39 \\
\hline GRAND BAHAMA & 46,994 & 15.48 & 51,756 & 14.63 \\
\hline ABACO & 13,170 & 4.34 & 16,692 & 4.72 \\
\hline ACKLINS & 428 & 0.14 & 560 & 0.16 \\
\hline ANDROS & 7,686 & 2.53 & 7,386 & 2.09 \\
\hline BERRY ISLANDS & 709 & 0.23 & 798 & 0.23 \\
\hline BIMINI & 1,717 & 0.57 & 2,008 & 0.57 \\
\hline CAT ISLAND & 1,647 & 0.54 & 1,503 & 0.42 \\
\hline CROOKED ISLAND & 350 & 0.12 & 323 & 0.09 \\
\hline ELEUTHERA & 7,999 & 2.63 & 7,826 & 2.21 \\
\hline EXUMA AND CAYS & 3,571 & 1.18 & 7,314 & 2.07 \\
\hline HARBOUR ISLAND & 1,639 & 0.54 & 1,702 & 0.48 \\
\hline INAGUA & 969 & 0.32 & 911 & 0.26 \\
\hline LONG ISLAND & 2,992 & 0.99 & 3,024 & 0.86 \\
\hline MAYAGUANA & 259 & 0.09 & 271 & 0.08 \\
\hline RAGGED ISLAND & 72 & 0.02 & 70 & 0.02 \\
\hline RUM CAY & 80 & 0.03 & 99 & 0.03 \\
\hline SAN SALVADOR & 970 & 0.32 & 930 & 0.26 \\
\hline SPANISH WELLS & 1,527 & 0.50 & 1,537 & 0.43 \\
\hline
\end{tabular}

\subsection{Climate and vegetation}

Climate ranges over the islands from subtropical temperate in the far north to semi-

arid in the far south. Rainfall patterns vary across the country. The northern part of the archipelago receives over 150 centimeters a year; the central area receives about 120 
centimeters a year, while the southern area receives less than 100 centimeters a year. In the southern islands evaporation rates tend to be higher than precipitation (Roebuck et al, 2004). Winters are mostly dry while summers are wet. The islands are all within the North Atlantic hurricane belt (Whitaker, 1997).

Vegetation types also vary spatially across the archipelago. The larger islands in the north support forests of Bahamian pine and palmetto, while in the central islands broadleaf coppice is found. Vegetation in the more arid southeastern islands is mainly low scrub. Soils are sandy and highly transmissive on all the islands with vadose zone of little more than one meter in many areas (Whitaker, 1997).

There are no true rivers or streams in the Bahamas. On the islands of Andros and San Salvador there are found a number of "bights" or "creeks" which are really estuaries and bays. These are marine features and not surface streams (Carew \& Mylroie, 1997).

\subsection{Geology}

According to geological time the Bahamas is young - about 150 million years old (Sealey, 1994). The islands were formed after the breakup of the supercontinent, after North America had separated from Africa and Europe and created the space which, when filled with water, became what we know today as the Atlantic Ocean (Sealey, 1994). They sit on a platform that was formed in shallow water along the edge of the new ocean. Over time the platform gradually subsided but the building near the surface continued. The islands are composed of carbonates precipitated from the ocean, and of sediments carried by wind and water and deposited over time (Sealey, 1994). As the ocean levels rose and fell during and between glaciations, the surfaces were in turn exposed and 
eroded by wind and water, and submerged and acted upon by the same elements. During the periods of sea level fall when more of the surface was exposed, features such as caves, banana holes, which are shallow sinkholes, blue holes, which are deep, inland, water-filled depressions, the marine form of which are known as ocean holes, were formed by the action of freshwater in the form of rain, creating a type of karst landscape (Carew \& Mylroie, 1997). One of the main landforms in the Bahamas is the eolian ridges that formed on the ocean sides reaching up to sixty meters in some areas. (The highest point in the islands is Mount Alvernia on Cat Island at sixty-three meters.) The other commonly occurring landform is that of lowland areas which occur between these ridges. Most of the surface is made of Pleistocene limestone on the interiors of the islands, while in coastal regions limestone of Holocene age is often found. The Pleistocene rock is covered with a red calcrete or terra rossa paleosol, unless it has been removed by erosion (Carew \& Mylroie, 1997). Within the Pleistocene limestone freshwater aquifers have been formed by rain that seeped down through the porous surface and settled on the saltwater. Freshwater aquifers also form in the Holocene sands in the southeastern islands and in the coastal areas of the northern islands. The size of the aquifer is limited by the size of the island. Holocene sand aquifers form in strands and beach sands. Extraction is more difficult from these aquifers, but there is potential for the retention of large amounts of freshwater in them (Whitaker, 1997). The Lucayan limestone aquifer is predominant in the islands of the Bahamas. Extraction from these aquifers is generally simple, via drilled wells, and in some low areas, by shallow, hand dug wells. Those that are near to coastlines can discharge directly into "bights" or "creeks", and thence into the ocean. Since most of the land area of the Bahamas is near 
sea level, the vadose zone in most areas is only about one meter thick. The porosity of these surfaces means that falling rain quickly infiltrates the soil producing little runoff. In both types of aquifers, evapotranspiration can occur directly from the aquifer due to the shallowness of the vadose zone. Often tree roots penetrate the aquifer, drawing water directly from within. Also, because of their shallowness, the aquifers are extremely vulnerable to pollution from the surface (Roebuck, 2004). Figure 3.1 is an illustration of the type of lens aquifer found throughout the Bahamas (Roebuck, 2004). The Bahamas is considered to be a water poor country with 61.92 cubic meters a year available per capita (FAO 2003).

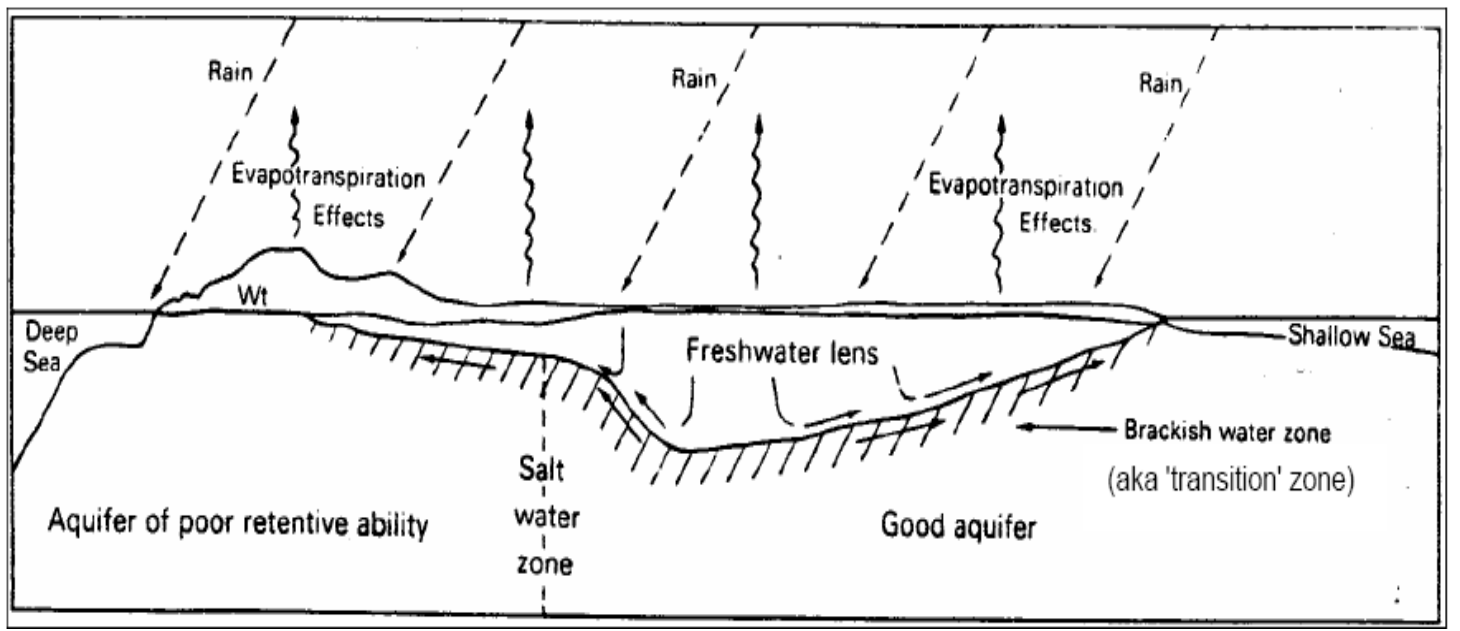

Figure 3.1 Illustration of Ghyben-Hertzberg lens aquifer found in the Bahamas (Source: Roebuck, 2004)

\subsection{New Providence island}

The island of New Providence, where this study is centered, is one of the northernmost of the islands and is designated one of the pine islands, which also includes Grand Bahama, Abaco, the Berry Islands, and Andros. It sits in an east-west direction 
on the edge of the Great Bahama Bank opposite Andros, across the deep extension of the Atlantic Ocean known as the Tongue of the Ocean. It is one of the smallest islands in the Bahamas chain but it is home to more than two-thirds of the residents of the country. New Providence has a total area of 200 square kilometers, or 51,200 acres (Cant \& Weech, 1980). A prominent eolian ridge runs along the north side of the island and a lesser ridge along the south side, with low lying areas between those ridges. Figure 3.2 illustrates the distribution of the ridges. There are a number of lakes on New Providence, the largest of which is Lake Killarney, a shallow, sometimes brackish lake near the western end of the island. Much of the island has been developed with densest population centered in the capital city of Nassau, where many impervious surfaces have been created in the form of roads, buildings, parking lots, and shopping centers. In the natural state, this island surface is highly permeable and water quickly sinks into the calcareous and sandy soils so that no natural perennial streams have formed. 


\section{New Providence Elevation}
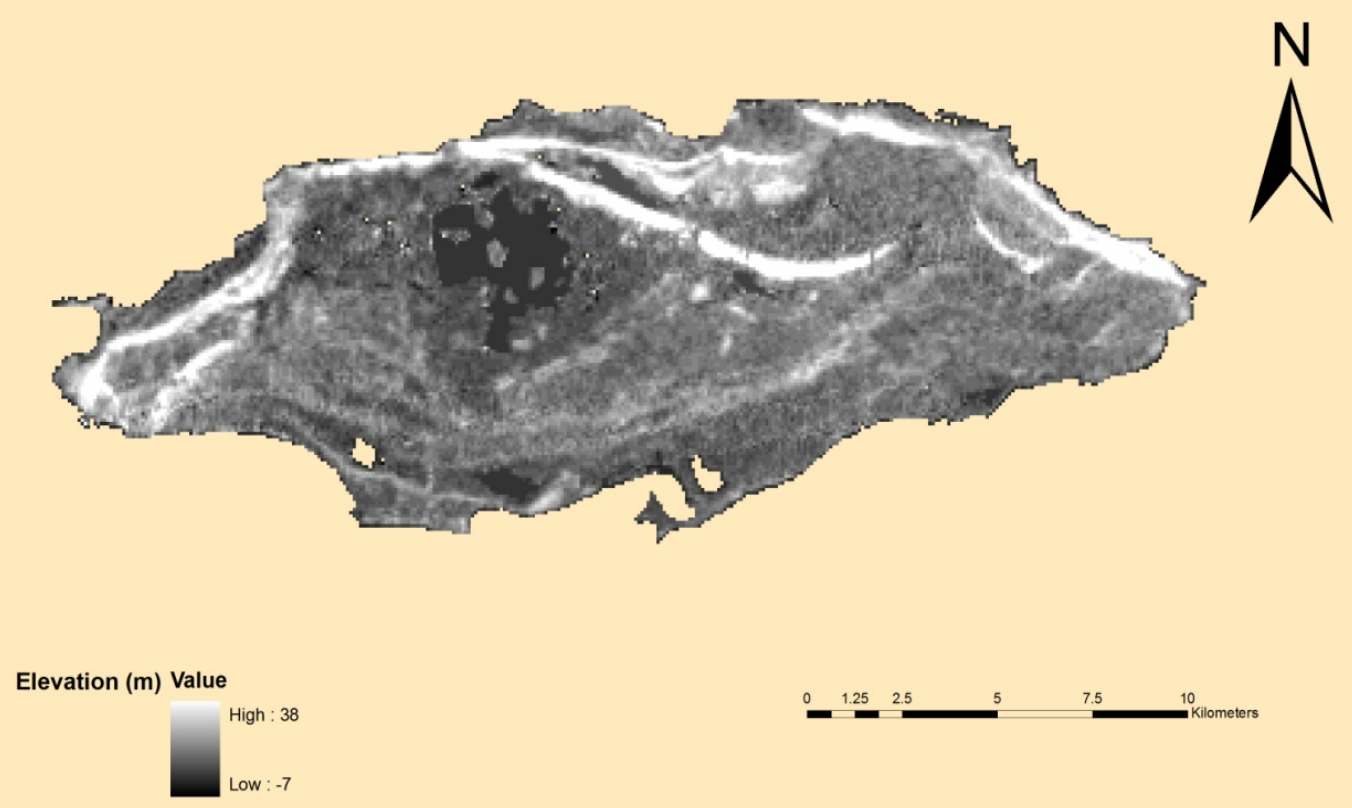

Figure 3.2 New Providence elevation map

The Island receives a generous amount of rainfall which varies over the year as well as from year to year. There is a definite wet and dry seasonal variation with most rainfall occurring during the summer months from May to October. Rain events are generally short and intense with sunshine returning shortly after the end of the rain. Annual rainfall totals vary from 100 centimeters to more than 170 centimeters. Figures 3.3 and 3.4 present the rainfall data for the island of New Providence that was obtained from the Bahamas Meteorological Office covering the period from 1971 to 2000. Average rainfall during this period was 140 centimeters. The measurements were taken at Nassau International Airport, which was the only location from which complete figures were available, and therefore the only rainfall data used in this study. 


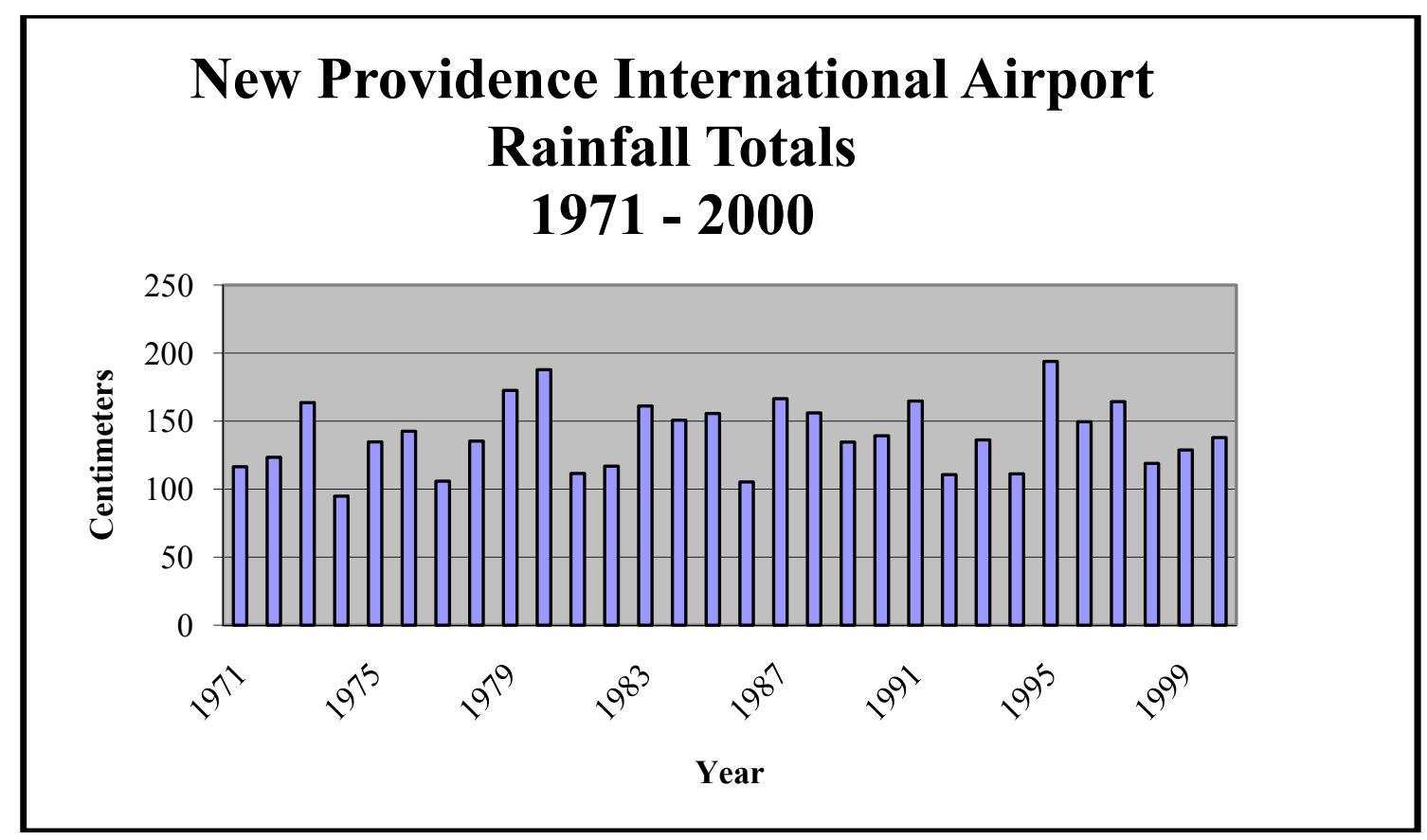

Figure 3.3 Rainfall average totals for NP 1971-2000 (Source: Bahamas Meteorological Office)

Figure 3.3 contains the figures for the period from 1971 to 2000 and illustrates the variation from year to year, which can be considerable. Figure 3.4 contains the average rainfall over the year showing the wet-dry seasonal pattern. 


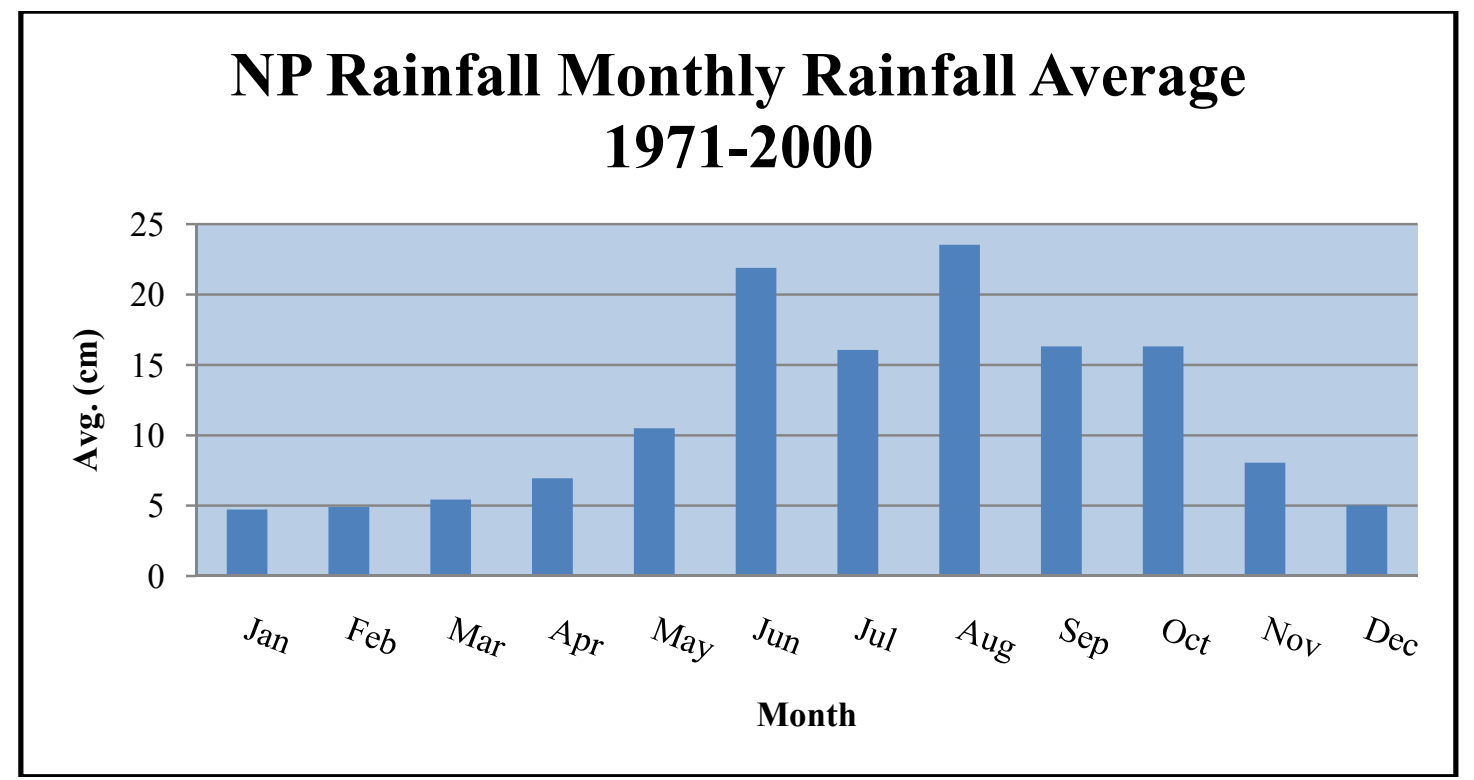

Figure 3.4 Monthly average rainfall totals for NP 1971-2000 (Source: Bahamas Meteorological Office)

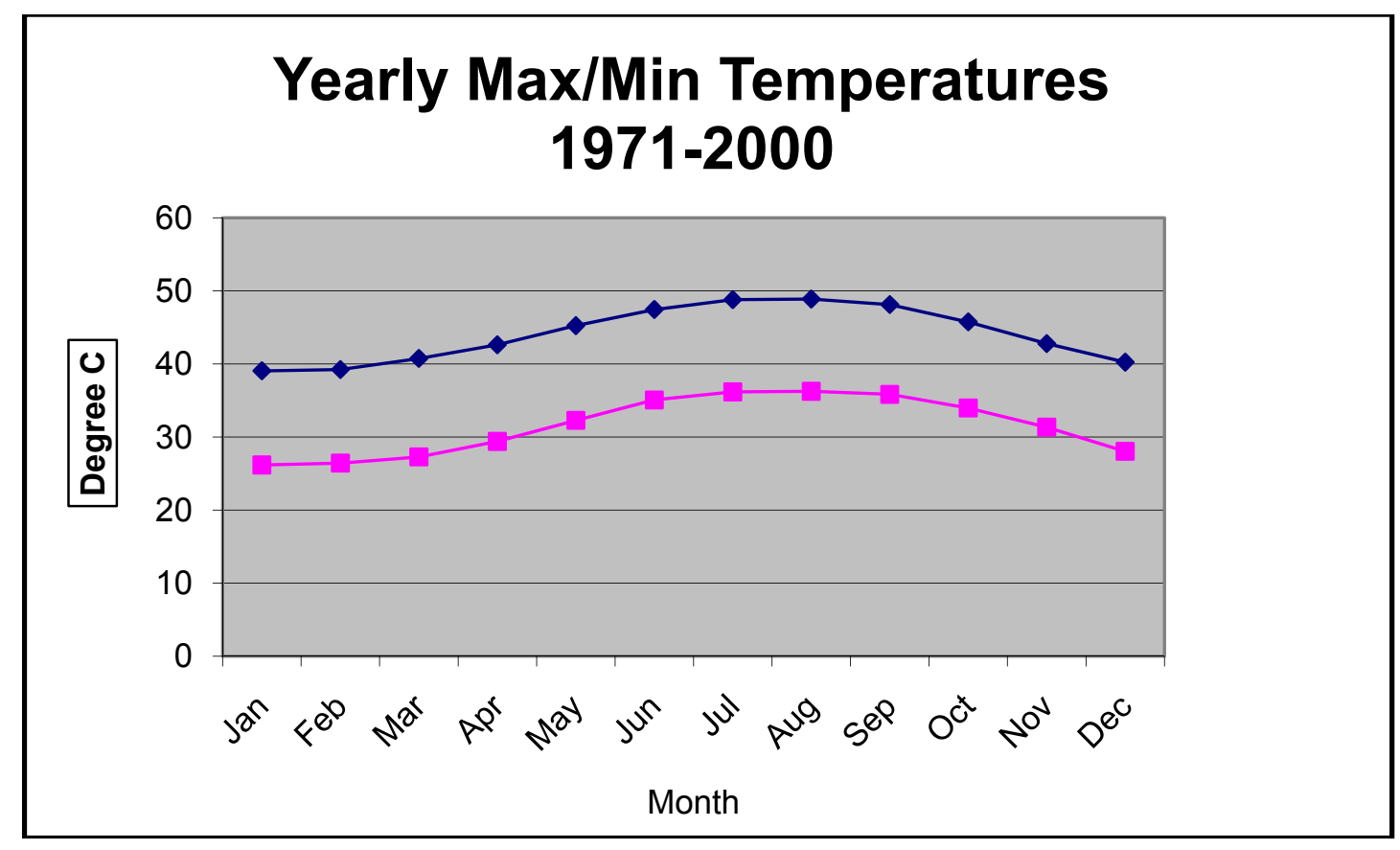

Figure 3.5 Average yearly maximum and minimum temperatures 1971-2000 (Source: Bahamas Meteorological Office) 


\subsection{Water resources}

The hydrogeology of New Providence is similar to the other islands, that is, Pleistocene limestone throughout most of the island with Holocene sands in coastal regions having Ghyben-Hertzberg type lens aquifers. There are nine aquifers which have a depth of greater than twenty feet thick located on New Providence (Table 3-2). They

Table 3-2. Capacity of aquifers on New Providence (Source: Cant \& Weech, 1980)

\begin{tabular}{|l|r|r|r|}
\hline \multicolumn{2}{|l|}{ New Providence Fresh Water Resources } & & \\
\hline Aquifer & Approx. Vol m & Max. lens thickness ft. Avg. lens thickness ft. \\
\hline Blair and Pinewood Gardens & $7,450,000$ & 36 & 25 \\
\hline East of Sea Breeze & 222,000 & 23 & 20 \\
\hline South Beach & $4,406,000$ & 24 & 20 \\
\hline Golden Gates & 616,000 & 22 & 20 \\
\hline Blue Hills Ridge & $6,229,000$ & 37 & 25 \\
\hline Prospect to Grants Town & $8,727,000$ & 30 & 25 \\
\hline Cow Pen Road & 493,000 & 25 & 20 \\
\hline South Lake Killarney & $3,489,000$ & 25 & 20 \\
\hline Western New Providence & $88,816,000$ & 50 & 30 \\
\hline
\end{tabular}

are distributed throughout the island with a total acreage of 17,503 acres. The total freshwater storage capacity of the New Providence aquifers has been estimated at $120,448,000$ cubic meters. The largest of these, the Western New Providence aquifer, is in the western section of the island and has a total storage capacity of $88,816,000$ cubic meters. The Prospect/Grants Town aquifer is second largest with 8,727,000 cubic meters of freshwater storage capacity, followed by the Blair and Pinewood Gardens aquifer with 7,450,000 cubic meters, Blue Hills Ridge with 6,229,000, South Beach with 4,406,000, and South Lake Killarney with 3,489,000 cubic meters. There are three small aquifers, 
Golden Gates, Cow Pen Road, and East of Sea Breeze with a total of 1,331,000 cubic meters combined (Cant and Weech, 1980). If all aquifers were producing, the maximum available water is estimated at 9,626,650 gallons per day (Cant \& Weech, 1980).

Water usage on New Providence is mainly for domestic purposes since there is little industry other than tourism. However, this is a high demand sector which raises water usage above that needed for the resident population. The tourism industry has grown rapidly over the last several decades and the water demand has risen concurrently.

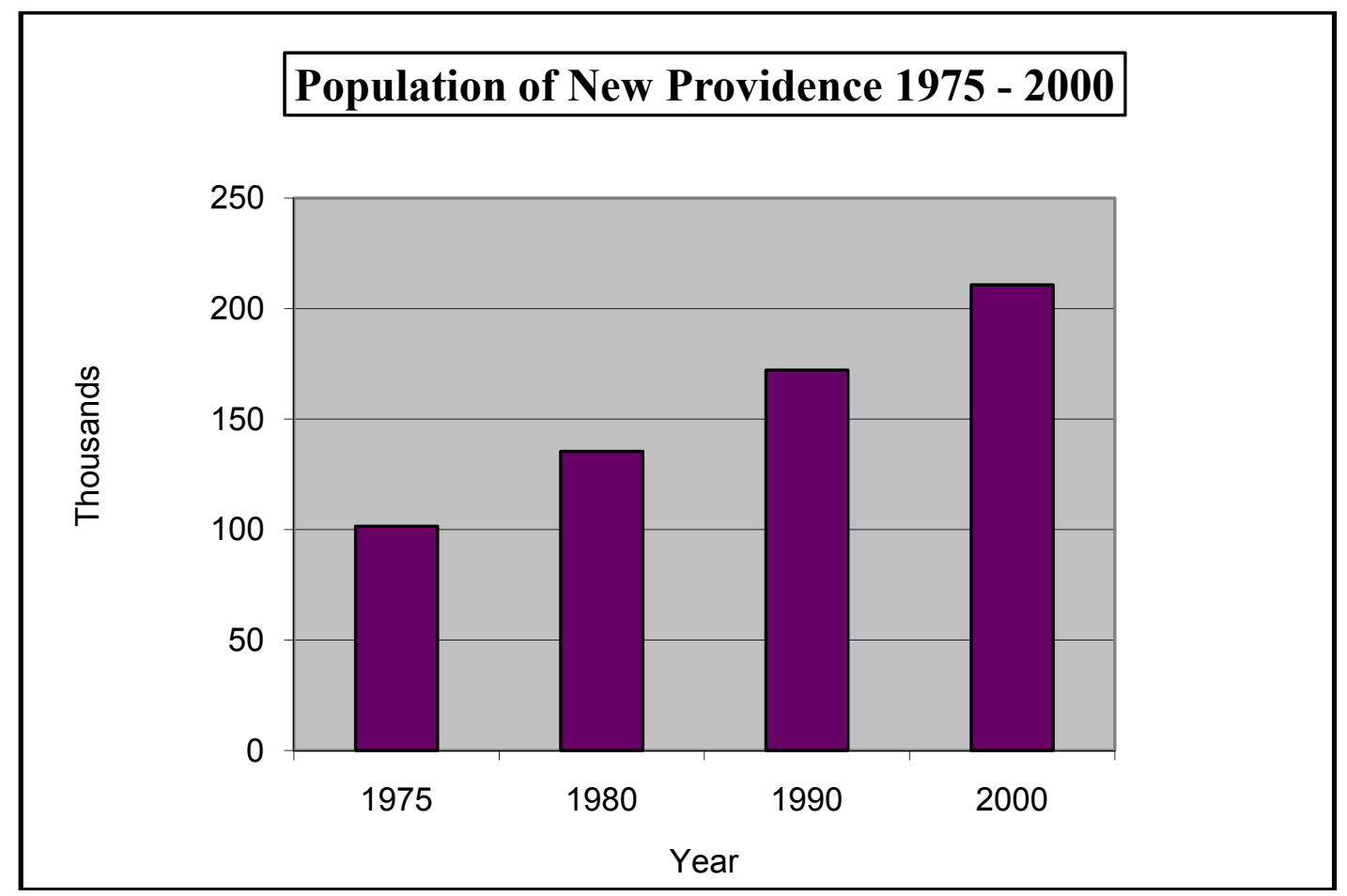

Figure 3.6. Population on New Providence (NP) 1975 to 2000 (Source: Bahamas Dept. of Statistics) 


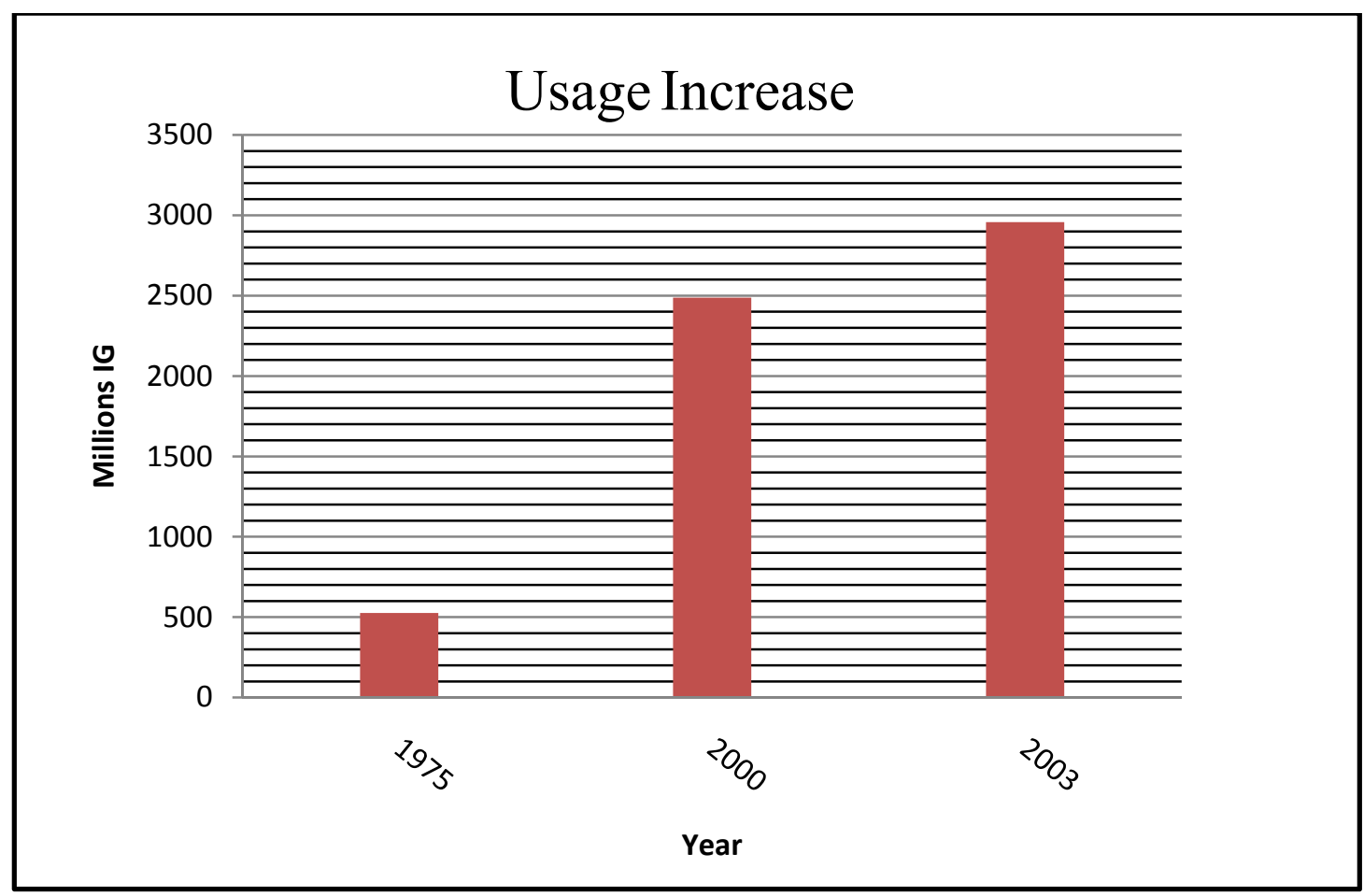

Figure 3.7.Water usage 1975 to 2003 in imperial gallons (IG) (Source: Bahamas Water \& Sewerage Corp.)

While the resident population of the country doubled from just over 150,000 persons to about 300,000 during the period from 1975 to 2000 (Dept. of Statistics), water usage increased more than five times in the same period (BWSC) as shown in Figures 3.6 and 3.7. The water usage of about nine million imperial gallons per day for New Providence is supplied from a variety of sources, with only about one-fourth from groundwater. Figure 3.8 contains the breakdown of extraction by pumping station. All pumping is from the Windsor wellfield in the western section of the island.

The major portion of freshwater production is from a combination of desalination and import. There are currently two reverse osmosis operations on New Providence producing almost five million gallons per day, while a total of over two million gallons per day is imported from the Island of Andros, forty miles away (see Figure 3.9). 


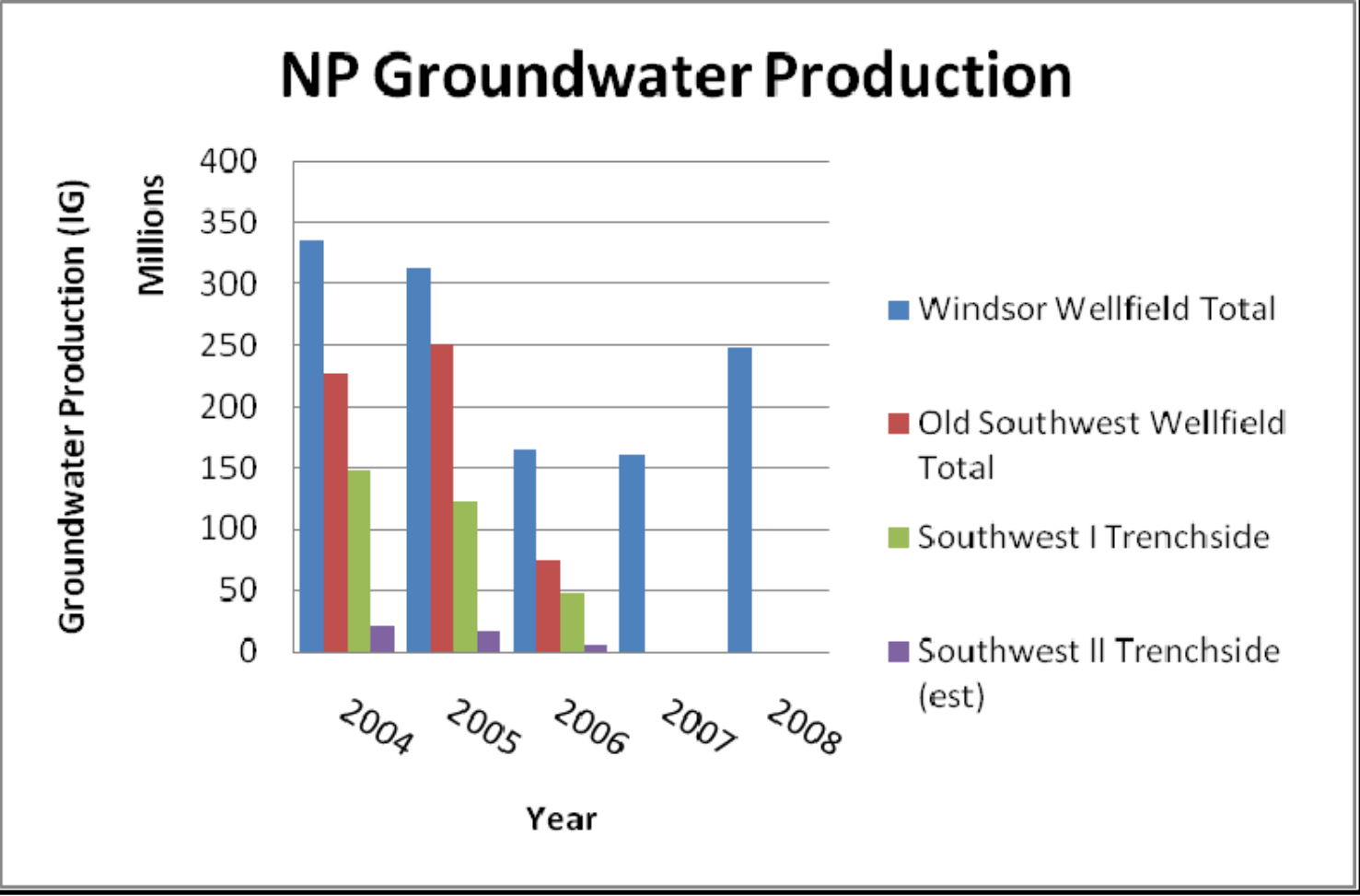

Figure 3.8 Groundwater production in imperial gallons (Source: Bahamas Water \& Sewerage Corp.)

Currently, only one of the aquifers, the Western New Providence, is producing freshwater. The others have been abandoned and have not been pumped by the water corporation for several years. The Blair aquifer is used by residents of the area who have drilled private wells, the number of which is not known, since they are not recorded (Cant, 2009). It is hoped that this water is not being used for drinking as it may be severely polluted (Cant, 2009). None of the aquifers other than the Western New Providence are being monitored for salinity or levels due mainly to a lack of trained personnel (Cant, 2009). 


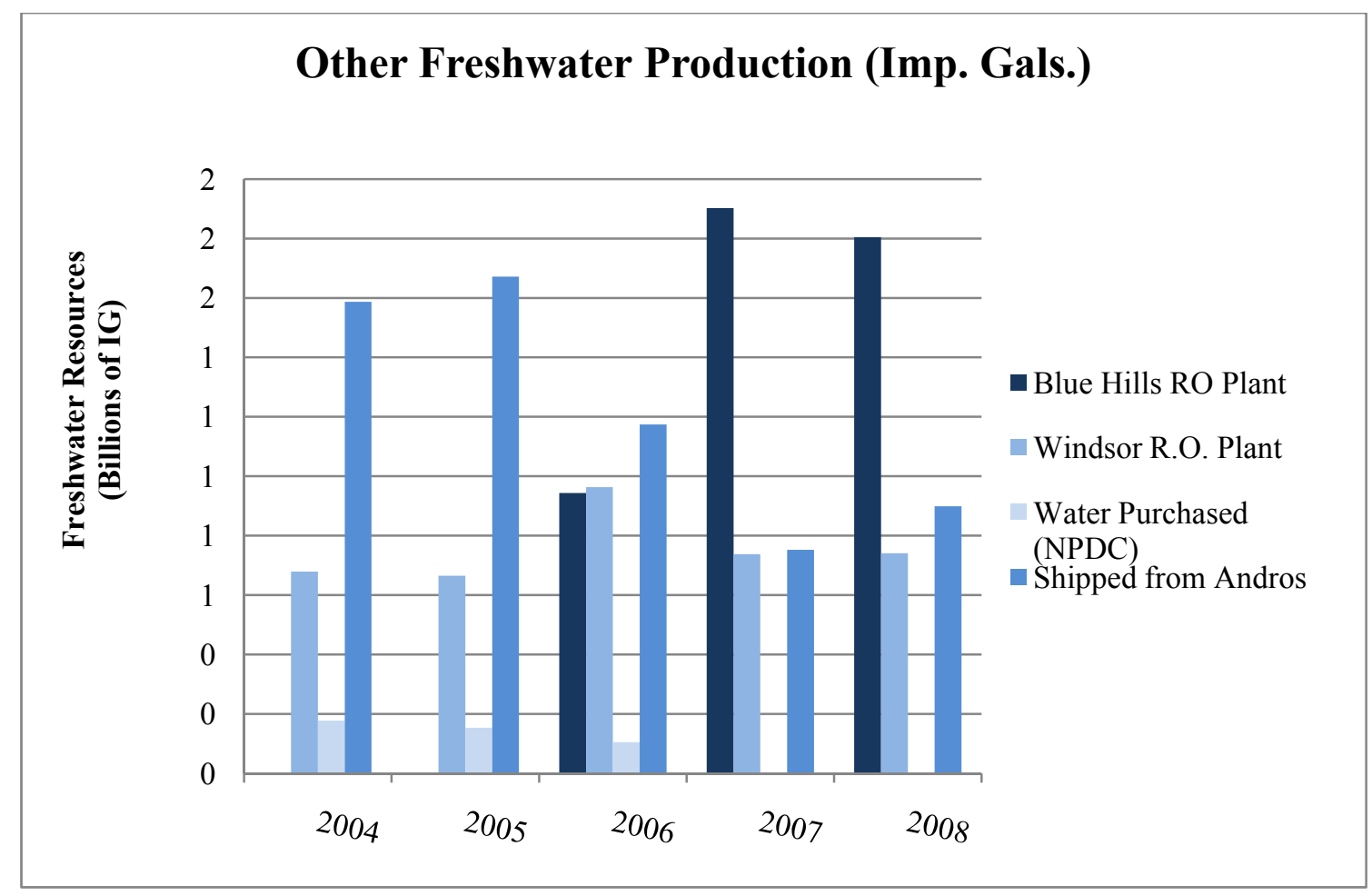

Figure 3.9 Freshwater production by reverse osmosis, purchase, and import from Andros (Source: Bahamas Water \& Sewerage Corp.) 
Table 3-3. New Providence freshwater production from all sources 2004 to 2008 (Source: Bahamas Water \& Sewerage Corp.)

\begin{tabular}{|c|c|c|c|c|c|}
\hline \multicolumn{6}{|c|}{ PRODUCTION 2004 - 2008} \\
\hline Source & 2004 & 2005 & 2006 & 2007 & 2008 \\
\hline & Imperial Gallons & Imperial Gallons & Imperial Gallons & Imperial Gallons & Imperial Gallons \\
\hline Jack's Pond & $69,283,100$ & $57,769,624$ & $10,433,300$ & $\begin{array}{l}\mathbf{0} \\
\end{array}$ & $\mathbf{0}$ \\
\hline Gravity Pit Extension & 0 & 0 & $\mathbf{0}$ & $16,846,800$ & $35,054,000$ \\
\hline Line 90 & $120,170,600$ & $126,841,300$ & $79,237,400$ & $82,922,600$ & $112,840,000$ \\
\hline Portable Diesel Pump(s) @ G.Pit & $\mathbf{0}$ & 0 & $\mathbf{0}$ & $\mathbf{0}$ & 0 \\
\hline Gravity Scheme & $145,022,600$ & $127,651,500$ & $76,316,000$ & $60,862,500$ & $100,197,000$ \\
\hline Windsor Wellfield Total & $334,476,300$ & $312,262,424$ & $165,986,700$ & $160,631,900$ & $248,091,000$ \\
\hline Windmills $1 \& 2$ & $1,984,270$ & $3, \mathbf{3 6 3 , 5 7 0}$ & $1,131,880$ & 0 & 0 \\
\hline Windmills 3 \& 4 & $3,501,360$ & $6,116,160$ & $1,081,100$ & 0 & $\mathbf{0}$ \\
\hline Million Air Field (3" Portable Diesel Pump) & $33,539,800$ & $42,797,300$ & $7,326,300$ & 0 & 0 \\
\hline G.H.T. Line & $46,271,000$ & $79,958,000$ & $19,146,000$ & 0 & 0 \\
\hline Eastern Extension (minusS/W 2) & $114,686,200$ & $92,156,700$ & $33,573,600$ & 0 & $\mathbf{0}$ \\
\hline Northern Extension & $27,569,000$ & $26,765,000$ & $11,257,000$ & $\mathbf{0}$ & $\mathbf{0}$ \\
\hline Old Southwest Wellfield Total & $227,551,630$ & $251,156,730$ & $73,515,880$ & 0 & $\mathbf{0}$ \\
\hline \multicolumn{6}{|l|}{ Southwest I Wellside } \\
\hline Southwest I Trenchside & $147,769,884$ & $122,112,402$ & $46,849,500$ & $\mathbf{0}$ & $\mathbf{0}$ \\
\hline Southwest II Trenchside (est) & $20,643,516$ & $16,430,890$ & $5,495,382$ & $\mathbf{0}$ & $\mathbf{0}$ \\
\hline Perpalls Wellfield & $6,093,000$ & $\mathbf{0}$ & $\mathbf{0}$ & $\mathbf{0}$ & 0 \\
\hline Prospect Wellfield & $65,841,000$ & $60,228,000$ & $26,233,000$ & 0 & 0 \\
\hline Prospect Scheme "E" & $\begin{array}{l}0 \\
\end{array}$ & $\begin{array}{l}\mathbf{0} \\
\end{array}$ & $\begin{array}{l}\mathbf{0} \\
\end{array}$ & 0 & 0 \\
\hline Blue Hills Wellfields & $8,408,000$ & $9,745,000$ & $\mathbf{0}$ & $\mathbf{0}$ & 0 \\
\hline Blue Hills RO Plant & $\mathbf{0}$ & $\mathbf{0}$ & $943,167,652$ & $1,902,578,000$ & $1,804,093,000$ \\
\hline Windsor R.O. Plant & $679,123,309$ & $665,144,145$ & $962,967,919$ & $737,853,035$ & $740,668,660$ \\
\hline Water Purchased (NPDC) & $177,684,847$ & $153,350,336$ & $104,746,400$ & 0 & $\mathbf{0}$ \\
\hline Shipped from Andros & $1,587,308,469$ & 1,671,921,112 & $1,174,239,882$ & $752,006,325$ & $899,093,358$ \\
\hline Total Water Production & $3,254,899,955$ & $3,262,351,039$ & $3,503,202,315$ & $3,553,069,260$ & $3,691,946,018$ \\
\hline
\end{tabular}

\subsection{Other water related issues}

The creation of impervious surfaces has created an additional problem - that of flooding of neighborhoods in low lying areas. The area receiving the most serious and frequent flooding events is a housing development in the southeastern area of the island called Pinewood Gardens (SSI, 2009). This area is most problematic as a result of its location between the high ridge on the north and a second ridge on the south, as well as the low level of most of the land. Other areas that experience flooding on a regular basis are west Bay Street, which is often inundated by flood water draining from the 
Chippingham area located on the high ridge running along the north central part of the area, the area along West Bay Street called Rocky Point, where streets are often closed for days at a time as a result of standing floodwater, and Stuart Cove at the southwestern end of the island, which also experiences frequent road closings due to storm water flooding (SSI, 2009) Historically, the method of dealing with these areas of flooding has been to drill drainage wells to try and remove the water from the flooded streets, but repeated maintenance problems have made these attempted solutions ineffective. 


\subsection{METHODS}

This chapter outlines and describes the curve number method used for my analysis to quantify the amount of rainfall available for recharge on a yearly basis. A description is provided of the GIS data that were acquired for use in the creation of land surface maps upon which to perform the analysis. Also, a detailed account of the selection of impervious areas and assignment of curve numbers is given.

\subsection{GIS and runoff calculation}

The method used in this analysis to calculate runoff is the curve number method that was developed by the United States Department of Agriculture, USDA Soil Conservation Service (later the Natural Resources Conservation Service or NRCS) and first published as Technical Report 55 (TR-55) in January 1975 under the title Urban Hydrology for Small Watersheds. The curve number method utilizes curve numbers which were determined on the basis of a number of factors including hydrologic soil group (HSG), cover type and treatment, hydrologic condition, and antecedent runoff condition (ARC). Sufficient data were not available to determine all of these factors, e.g., ARC, thus curve numbers were chosen from the look-up table of TR-55 for urban areas on the basis of the data in hand. The Bahamas Public Works Department provided geographic maps of the New Providence roads, plots, and a set of aerial photographs for the island that were made in the year 2000. These layers were used to determine the area of impervious surfaces and to create a GIS layer to be used in the calculation. The runoff was calculated using the equation: 


$$
Q=\frac{(P-I a) 2}{(P-I a)+S}
$$

where

$\mathrm{Q}=\operatorname{runoff}(\mathrm{in})$

$\mathrm{P}=$ rainfall (in)

$\mathrm{S}=$ potential maximum retention after runoff begins (in) and

$\mathrm{I}_{\mathrm{a}}=$ initial abstraction (in)

Initial abstraction $\left(\mathrm{I}_{\mathrm{a}}\right)$ includes all water that is lost before runoff begins, and includes water that is retained on the surface in depressions and water that is held by vegetation. It also includes evaporation and infiltration. Studies of many small watersheds have shown that $I_{a}$ can be approximated by:

$$
I a=0.2 S
$$

In order to remove $I_{a}$ as an independent parameter, Equation 2 was substituted into Equation 1 yielding the following:

$$
Q=\frac{(P-0.2 S) 2}{(P+0.8 S)}
$$

$\mathrm{S}$ is related to the soil and land cover of the watershed through the curve number, which has a range of 0 to $100 . \mathrm{S}$ is determined using the equation

$$
S=\frac{1000}{C N}-10
$$

A weighted curve number for a watershed can be calculated using the equation

$$
C N(\text { weighted })=\frac{\sum C N x \text { Area }}{\sum \text { Area }}
$$




\subsection{Suitable recharge areas}

In any management plan for artificial recharge of aquifers it is necessary to choose locations based on a number of factors. One of the most important of these factors is the slope of the land as this determines the direction in which the water will flow and where it will accumulate. Slope can be calculated in GIS using a digital elevation model (DEM). Other factors, such as infiltration rate, land use/land cover, and geology are important factors as well as location of aquifers and depth to water table. On the small island of New Providence there is little variation in most of these factors other than slope and land use. The ridges that run along the north and south sides of the island effectively direct runoff either to the sea or to the low-lying areas between them. The built areas such as roads and other impervious structures determine the quantity of runoff that will be directed.

For my study, slope was determined using a 90m Shuttle Radar Topography Mission (SRTM) raster layer. Since the island has no rivers or perennial streams, a roads network was used as a stream network in the runoff analysis. Additional data in the form of an Excel spreadsheet of drainage wells were provided by the Public Works Department and were converted to GIS layers for the purpose of illustrating the areas of the island that are subject to flooding.

\subsection{Data used}

Data were gathered from a number of sources and in a variety of formats. For the analysis of runoff, it was necessary to understand the surface of the land and the fate of 
rain that falls upon it. To form a comprehensive picture of the island, geographic layers were needed that represent land cover, elevation and locations of freshwater aquifers. To analyze runoff it was necessary to determine areas of impervious surfaces by means of zoning and use, and paved road. These were obtained from the Bahamian Government 2004 ARC Info dataset with aerial photographs, two foot contours, and roadway coverages supplied by the Bahamas Ministry of Works and Transportation.

The GIS layers of land cover and fresh water lens for the entire Bahamas were obtained from The Nature Conservancy (TNC) where they had been created by digitizing topographic maps supplied by the Department of Lands and Surveys from 1968-1975 at 1:10,000 scale. Political boundary and digital elevation layers were purchased from MapMart and were brought to UTM projection, like the TNC layers. Excel spreadsheets with drainage wells and catch basins to the sea were provided by the Ministry of Works and Transport.

\subsection{Preparation of data}

A personal geodatabase was created using the Environmental Systems Research Institute (ESRI) ArcGIS ArcCatalog and the following GIS layers were imported: Bahamas land cover, Bahamas freshlens, Bahamas political boundaries, New Providence plots, roads, and Bahamas digital elevation model, a Shuttle Radar Topography Mission (SRTM) raster layer. The geographic coordinate system was set to North American 1983 and projected to NAD_1983_UTM_Zone_18N. 


\subsection{GIS data preparation}

The first step in preparing the GIS data was to extract the data for New Providence from all the layers. I used the extraction tools in ArcMap 9.3 to obtain political boundaries, land cover, freshwater lens, and digital elevation model.

In order to calculate the amount of runoff, impervious surfaces had to be identified as follows. The areas designated "human altered lands" were extracted from the land cover layer and used as a mask to select roads and plots. Initial selection of plots and roads was made: roads were selected that fell within areas designated as human altered lands on the land cover layer; plots were selected in the same manner as shown in Figures 4.1 and 4.2. The roads layer as obtained was a polyline layer which did not represent the area of the roadways, so a five-meter buffer was applied to both sides of the selected roads. The figure was chosen as an average since the width of the roads was not available and in the heavily developed downtown areas, most of the easements have been paved over, becoming part of the roadways, so these areas were included in the buffer.

After these initial selections were made, the next step was to verify land use by determining which of the selected plots actually had structures on them. I overlaid aerial images and selected plots and inspected each for a structure as shown in Figures 4.3 and 4.4. By this method a total of 45,705 plots were found with structures. These were then classified according to zoning/use and area of plot, as well as size of structure. Finally, curve numbers were added to the table of roads and plots following the TR-55 lookup table. 


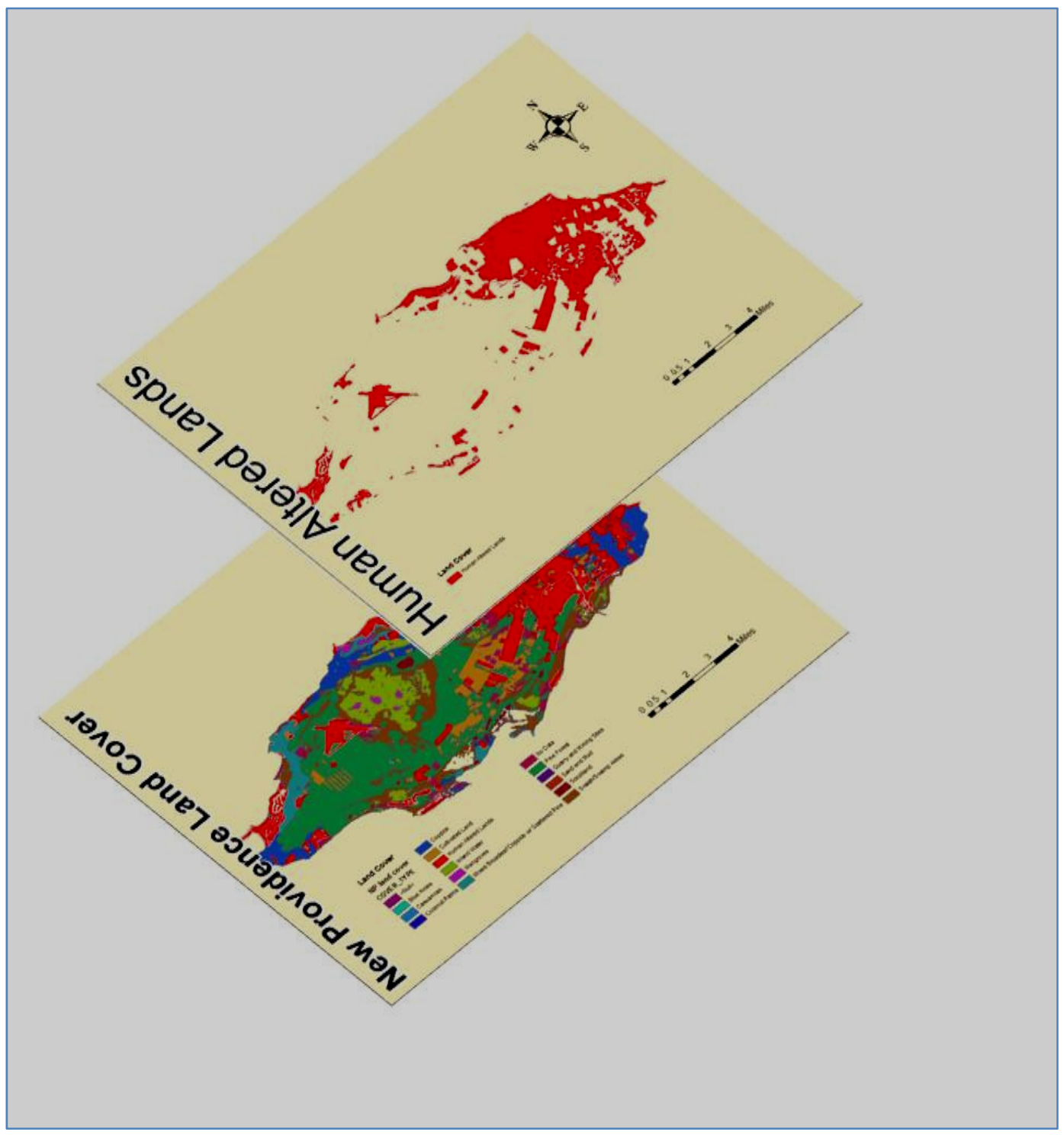

Figure 4.1. Human altered lands extracted from New Providence land cover layer. 


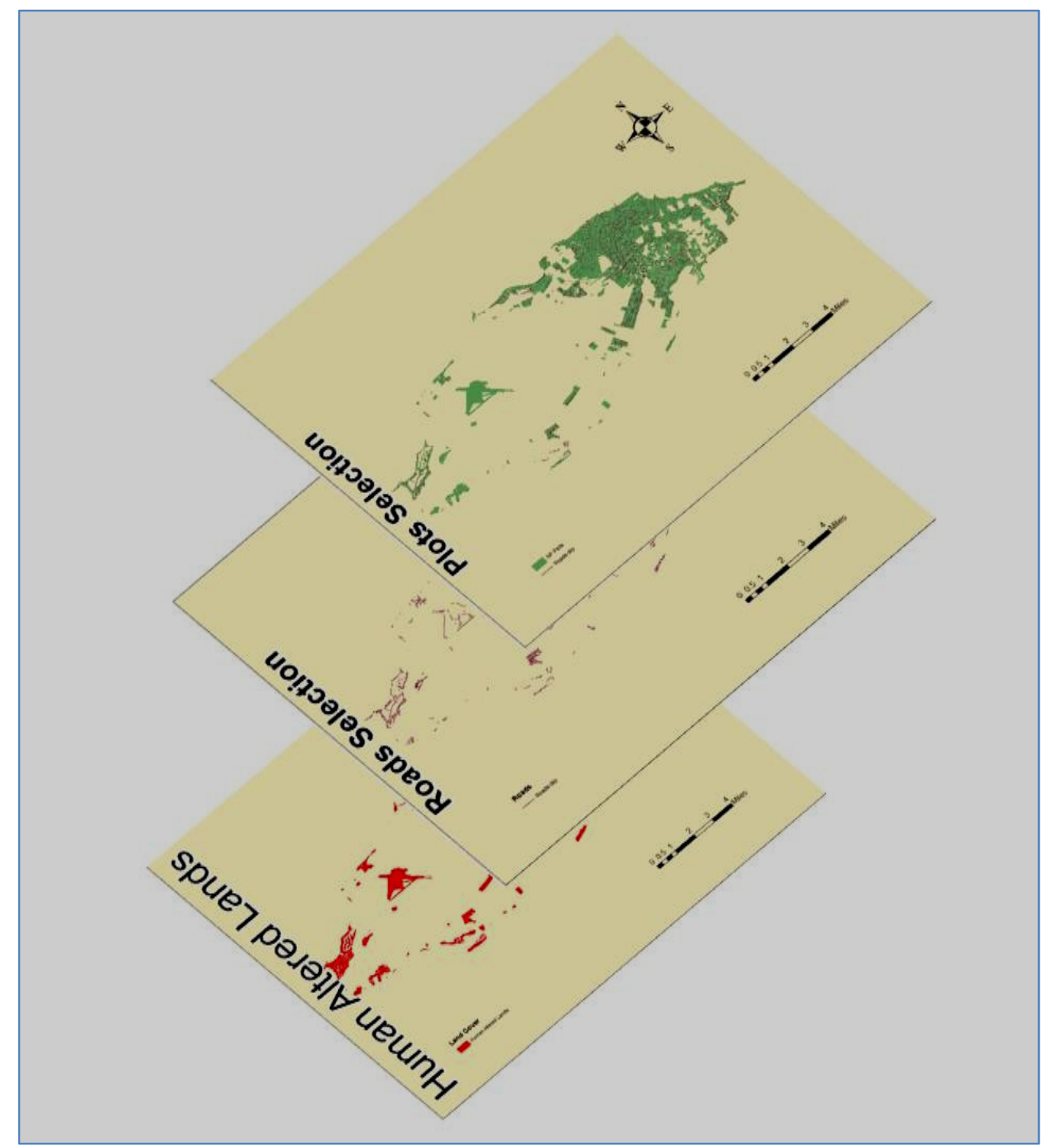

Figure 4.2. Roads and zoning plots corresponding with human altered areas extracted. 


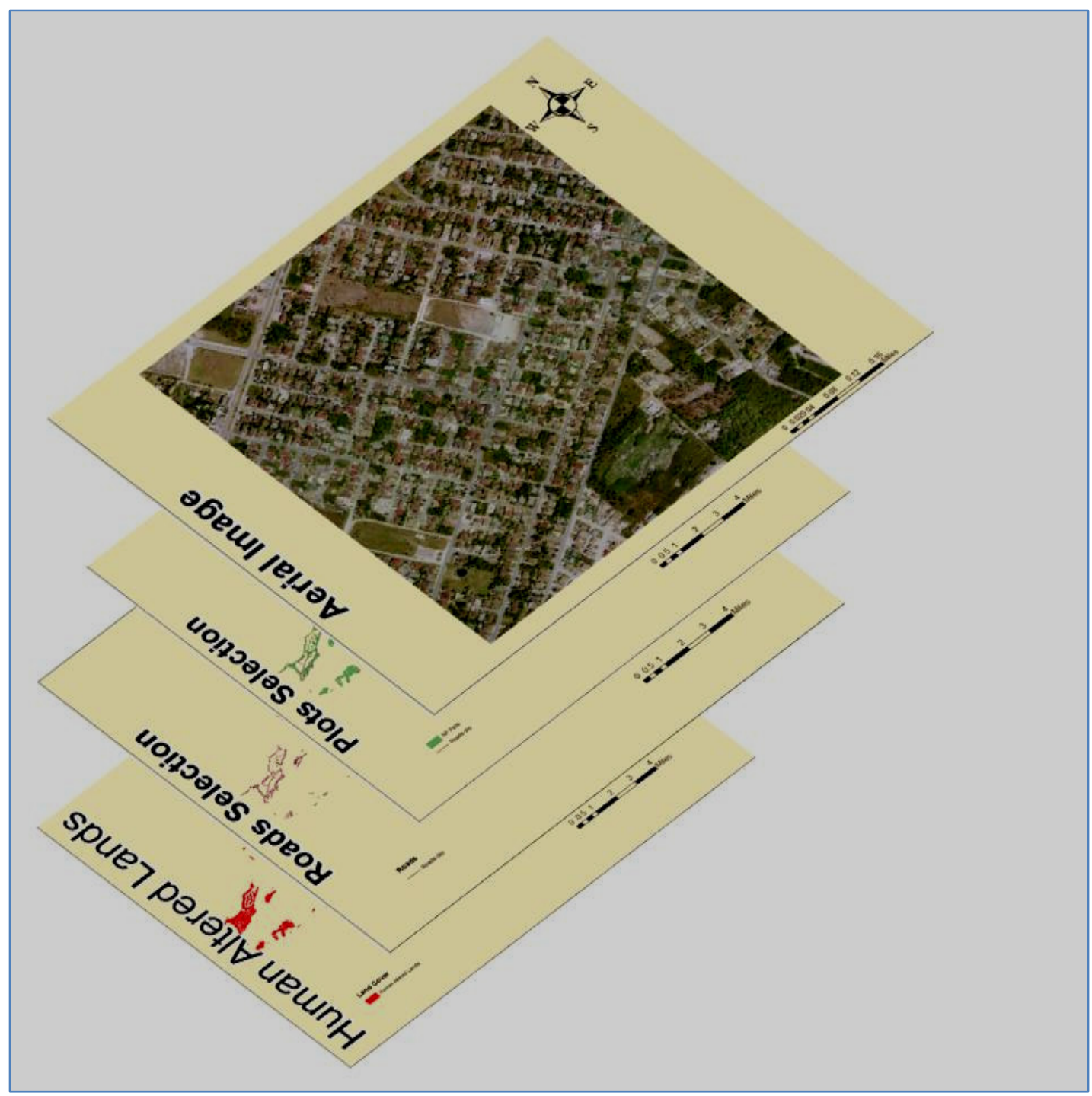

Figure 4.3 Aerial images overlay roads and plots for data extraction. 


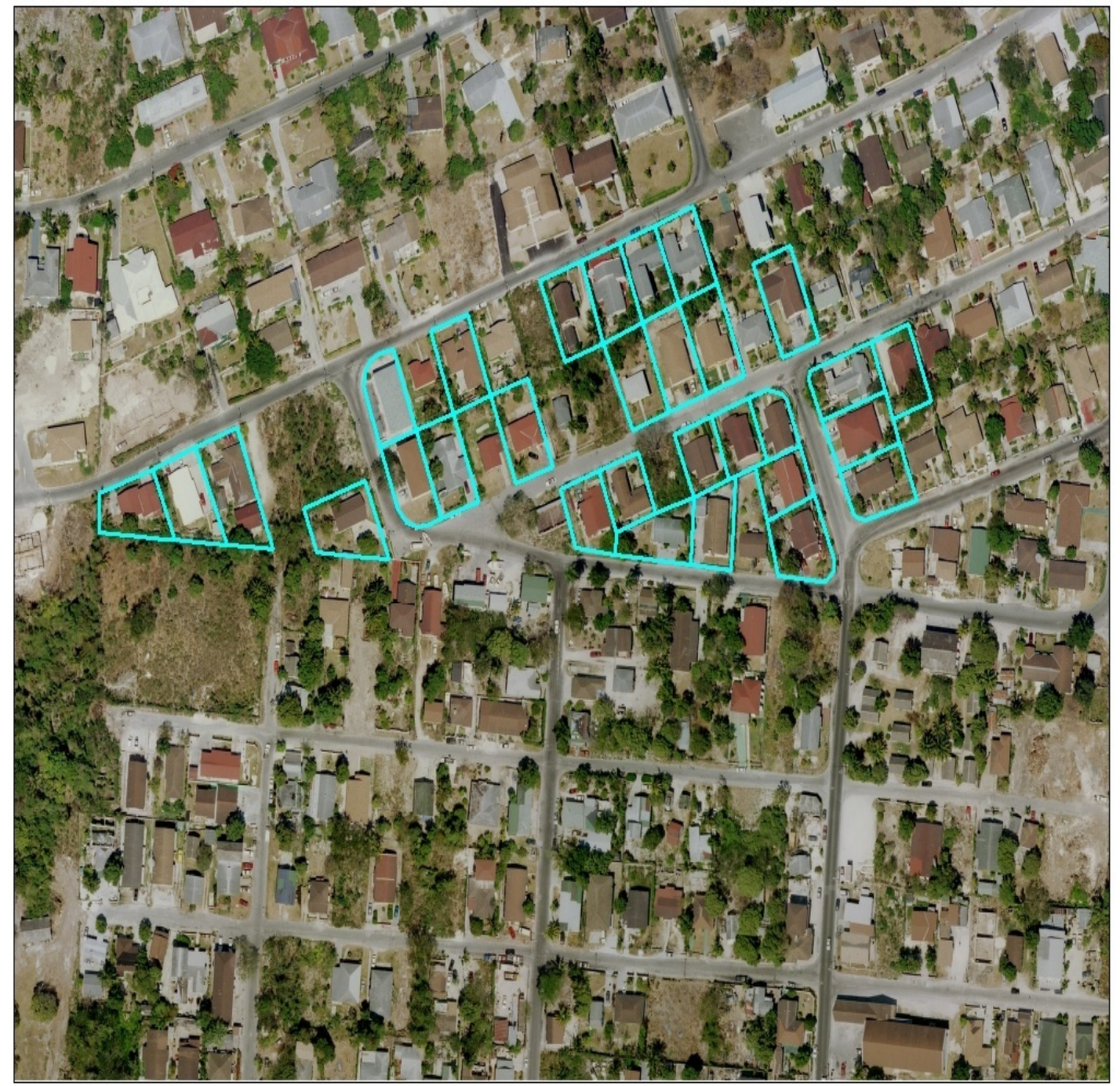

Figure 4.4 Selection of plots using aerial image 


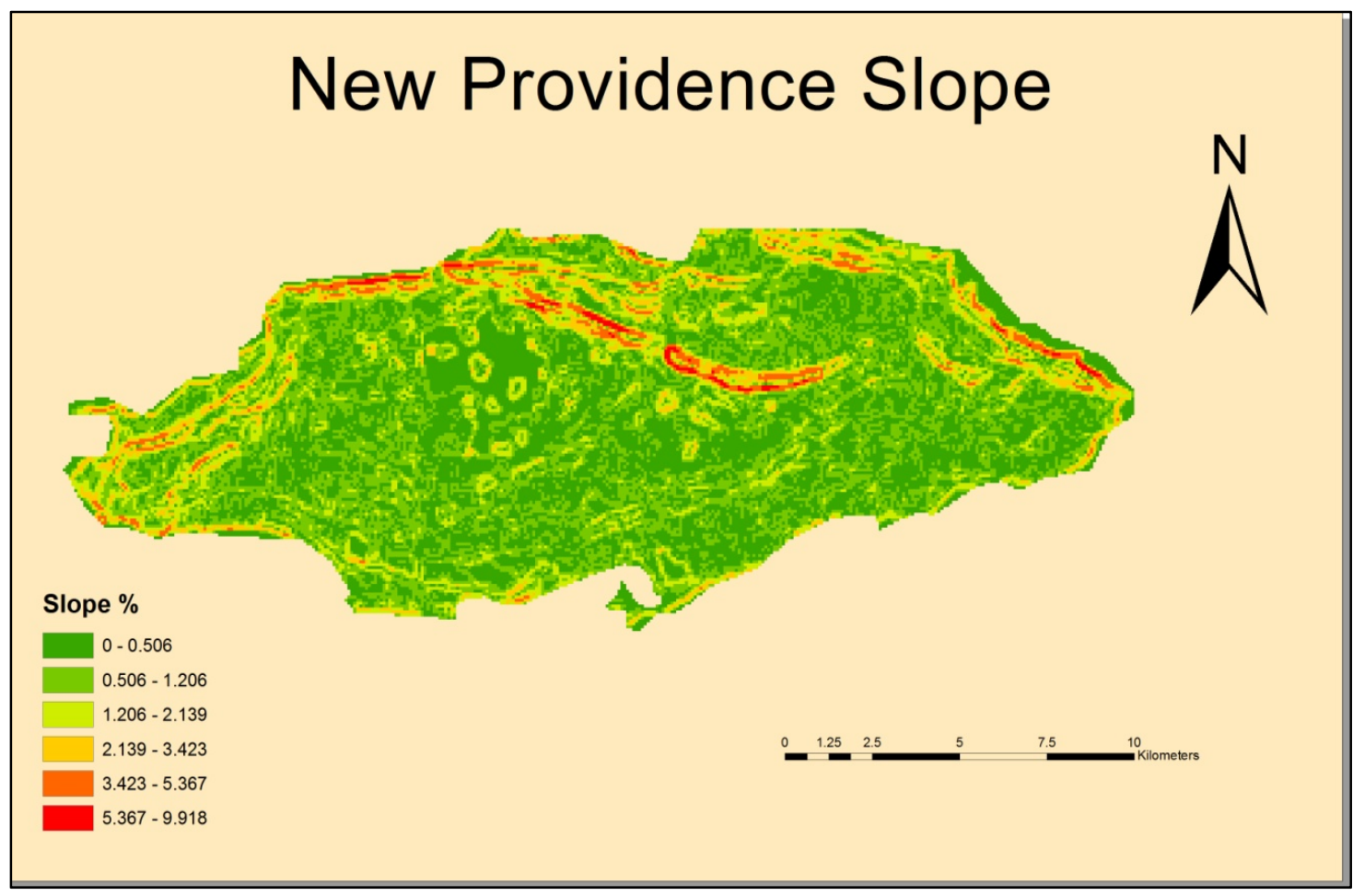

Figure 4.5 Slope percent derived from digital elevation model.

\subsection{Selection of recharge locations}

A slope percentage layer was generated in ArcMap from the digital elevation model layer using the Spatial Analyst tool. The selection of suitable recharge locations was based on three factors: elevation, slope, and proximity of aquifers. The raster calculator was used to generate a layer that met the specification [Elevation] $>=7 \&$ [slope_perc] $<$ 5. Seven meters of elevation was chosen in order to allow for the proximity of the aquifers to sea level. Slope percent of less than five percent was chosen as this has been shown to be suitable for recharge surfaces (Ghayoumian 2007). 


\subsection{Curve numbers}

Plots were assigned curve numbers based on zoning and land use and verified using aerial photographs. Designation of plots zoning/land use was made using the lookup table (Appendix 1) as follows:

T - Townhouses

SF - Single family

MF - Multi-family

D - Duplex

MU - Mixed use

$\mathrm{C}-$ Commercial

IP - Institutional public

IG - Institutional semi-public

The process described in the TR-55 flow chart (Appendix 2) was used to select suitable curve numbers from the lookup table. The land cover types were designated either residential or non-residential and then further classified according to individual type as shown in Figure 4.6.

\subsection{Weighted curve number}

In some areas it was necessary to calculate weighted curve numbers because of lack of data for individual surfaces. Weighted curve numbers were used for the roads network 
since two types of roadways exist on NP - roads with gutters and curbs and roads with swales. The roads in the older and more heavily populated parts of the city of Nassau are of the type having curbs and gutters, whereas roads in more recently developed areas tend to have more swale areas. Therefore, a weighted curve number was calculated for the combined roadways using the formula described above. To simplify the process, roads in the downtown area were selected using graphics in ArcMap; an oval was drawn around the most densely populated areas and roads corresponding to this shape were assigned a curve number according to the lookup table. The selection was switched and the remaining roadways were highlighted and assigned a curve number. A weighted curve number was also calculated for duplex properties based on the area of the lots. Worksheet 2 from the TR-55 manual (Appendix 3), was used in this process. Once curve numbers had been determined for each land cover type, the map table was edited in ArcMap to add curve numbers, precipitation, $\mathrm{S}$ value, runoff depth, and runoff volume in order to complete the calculations. 


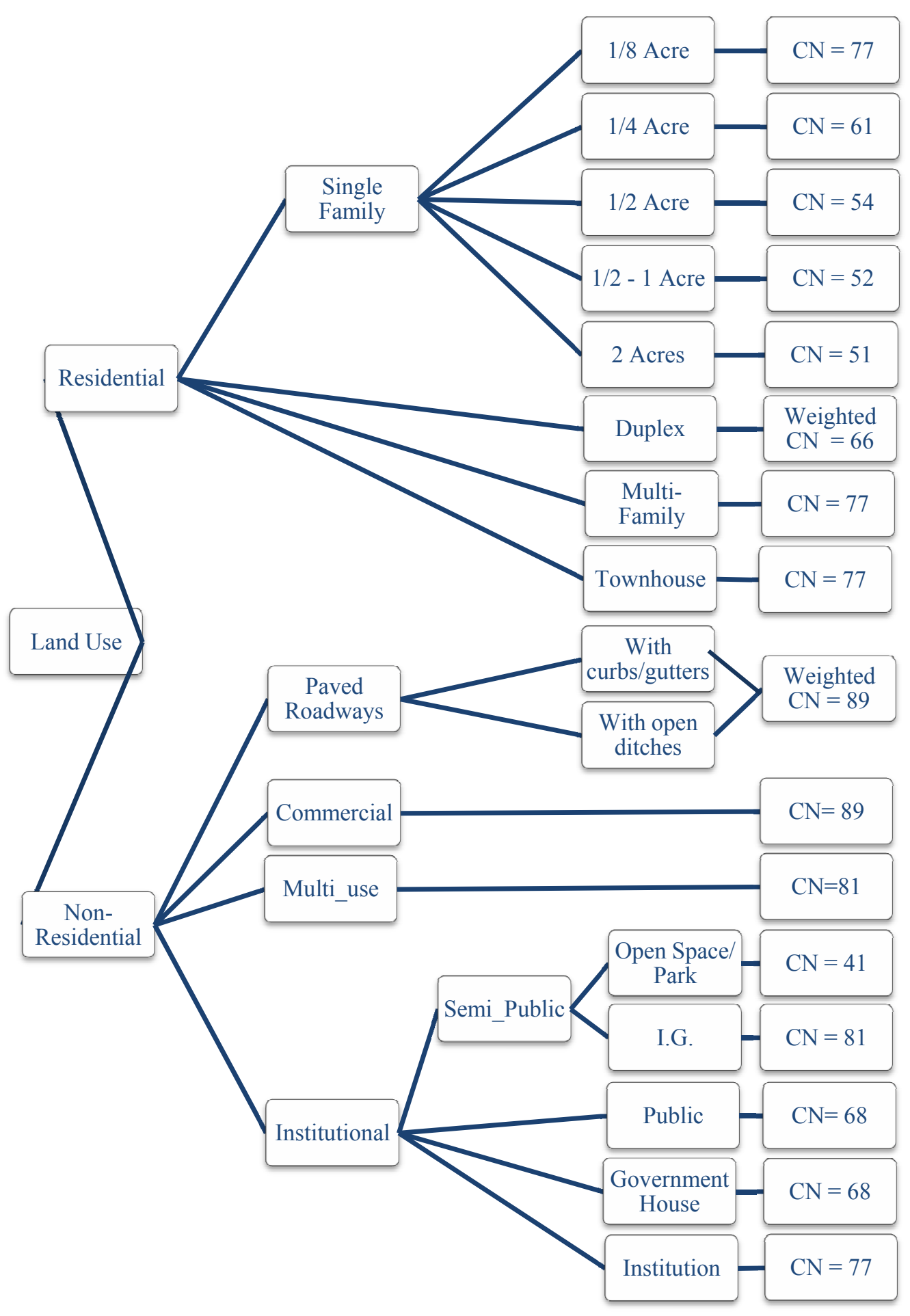

Figure 4.6. Tree to selection of curve numbers 


\subsection{RESULTS AND DISCUSSION}

The results from my analysis are presented in this chapter and the implications are discussed. This analysis shows that a substantial amount of runoff is created by the impervious surfaces on New Providence with highest depths in the downtown area of Nassau. Finally, the areas selected as most suitable for artificial recharge are shown.

\subsection{GIS maps and calculation}

Runoff depth and volume were calculated in ArcMap using the curve number method as outlined in sections 4.1 and 4.6 of this paper. The runoff table was edited and fields added to include precipitation amount in inches, curve number value, value of the parameter S, runoff depth and volume. The calculation of runoff depth was performed using the runoff equation Depth $=(\operatorname{Prec}-0.2 * \mathrm{~S}) *(\operatorname{Prec}-0.2 * \mathrm{~S}) /(\operatorname{Prec}+0.8 * \mathrm{~S})$ and is presented in Figure 5.1. Volume was calculated by converting depth to meters using the conversion one meter $=39.37$ inches so that results could be obtained in cubic meters.

\subsection{GIS runoff depth}

Runoff depth on impervious surfaces is shown to be greatest in the most intensely developed areas of the City of Nassau. In these areas almost all the surface has been paved or built over and most of the rainfall is converted to runoff and here the runoff depth ranges between 1.037 and 1.36 meters. Since many of these areas are also at higher elevations, they are the source of flood water in the lower elevations between the ridges. 


\section{Runoff Depth}

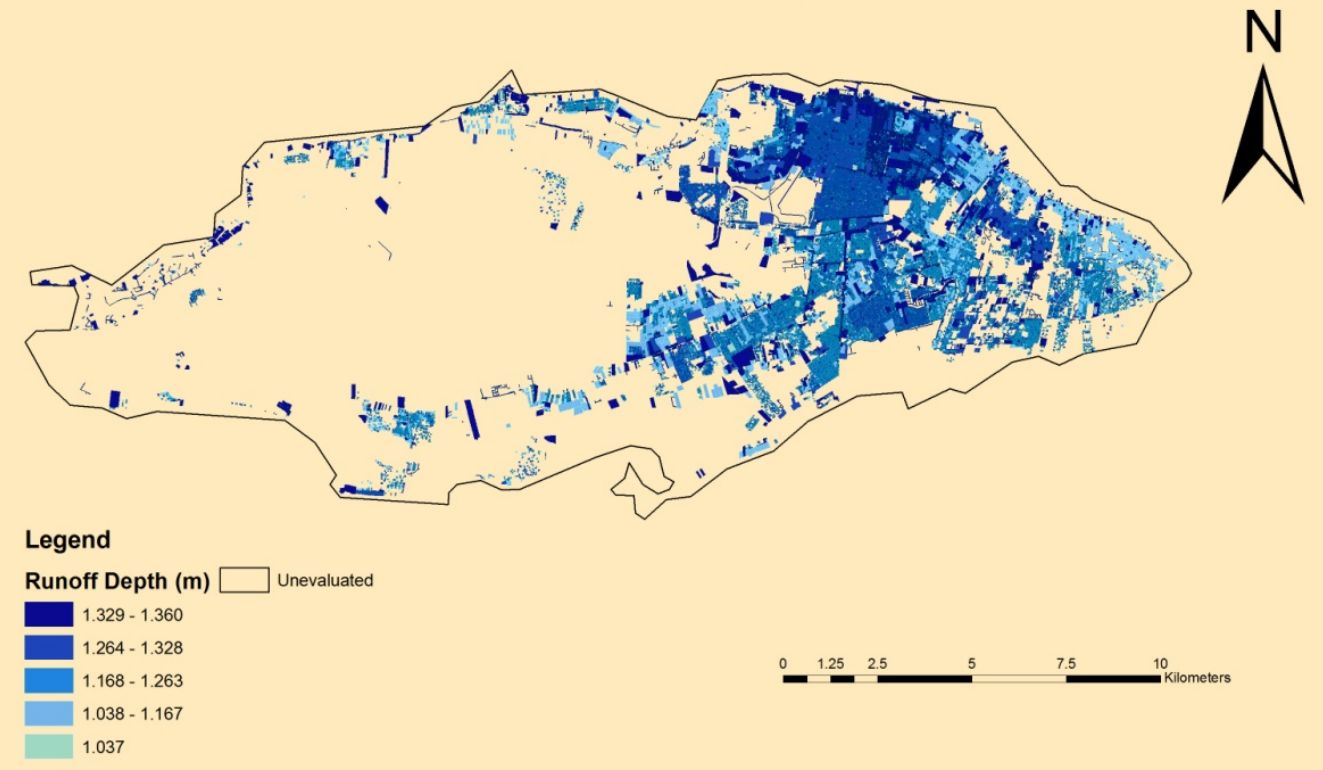

Figure 5.1 Average yearly runoff depth in meters based on average rainfall for 1971-

\subsection{GIS runoff volume}

2000.

Volume of runoff as calculated on impervious surfaces totaled $69,980,154 \mathrm{~m}^{3}$ on a yearly basis. (Converted to imperial gallons, which are used as the units of measurement in the Bahamas, this totals $15,393,465,413$ IG.) Not all of this runoff will be available for artificial recharge as some of it will be lost to the ocean in direct runoff and some will remain on the surface to be evaporated. Approximately twenty five percent of rainfall eventually reaches the groundwater aquifer (Sealey, 1995) under normal conditions where vegetation is present, therefore it can be conservatively estimated that $17,495,038$ $\mathrm{m}^{3}$ could be added to the freshwater supply on New Providence each year if this resource were carefully managed. Since this runoff is generated on the impervious surfaces that are clustered in and around the city of Nassau, those aquifers in the eastern area will benefit from harvesting of this water. Furthermore, since the surfaces that are generating 
this runoff are mostly devoid of vegetation, it can be surmised that this conservative estimate is much lower than what may be captured by efficient management.

\subsection{Suitable recharge locations}

Determining suitable locations for artificial recharge of aquifers will be influenced by several characteristics of the watershed (Ghayoumian et. al., 2007). Depth to aquifer is one parameter that must be considered. In New Providence, depth to groundwater is generally very shallow and can even be too shallow to be suitable for recharge since excessive ponding of water would occur and evaporation would claim much of it. It would be more desirable to locate recharge areas in places where there is enough depth so that the natural process of filtering of impurities from the water as it passes through the subsurface would be maximized. Areas suitable for artificial recharge were selected on the basis of elevation of seven meters or greater and slope less than five percent and overlaying an aquifer. The results are shown in Figure 5.2. The eastern section of New Providence has been most intensely developed with a mixture of residential, commercial, and industrial uses. Zoning regulations have been lax or nonexistent and the result is that much of the land has been completely covered with impervious surfaces (SSI, 2009). Much of the western section of the island is held by the Bahamas Government and is forested with pine. This is a protected area that overlays the largest freshwater aquifer, which is normally recharged, therefore little opportunity or need for artificial recharge exists there. The areas in the eastern section, outlined in red in Figure 5.2, are where artificial recharge would be most beneficial as the aquifers there are the ones that have been subjected to over-pumping and pollution from the surface. Here is where the need 
for artificial recharge exists as well as the opportunity for relief from flooding because of runoff from the impervious surfaces. However, as a result of the intense development, any plan for artificial recharge will be met with a number of challenges.

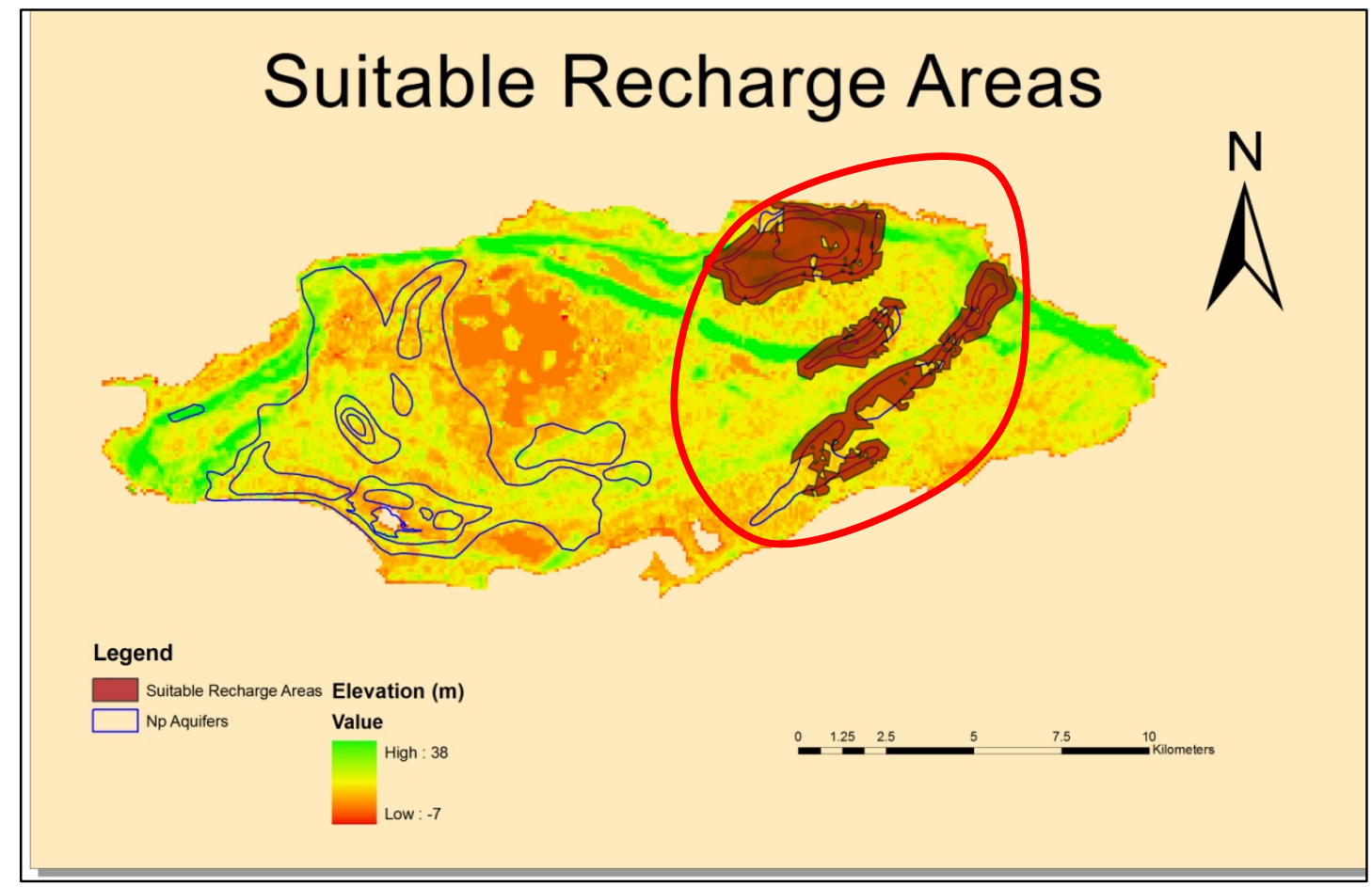

Figure 5.2. Suitable recharge locations

The first of these challenges will be cost, both to secure enough land to construct spreading basins as well as to prepare the surface, grade roadways and construct channels to direct the runoff to those basins. One option would be to use the aquifer storage and retrieval method described in Section 2.5. Since a large number of drainage wells already exist (Figure 5.3), it may be possible to convert some of these to recharge and add filters to help purify the water. There is little doubt that many of these wells are contributing to pollution of the aquifers (SSI, 2009) and this method presents the opportunity to reverse that. 


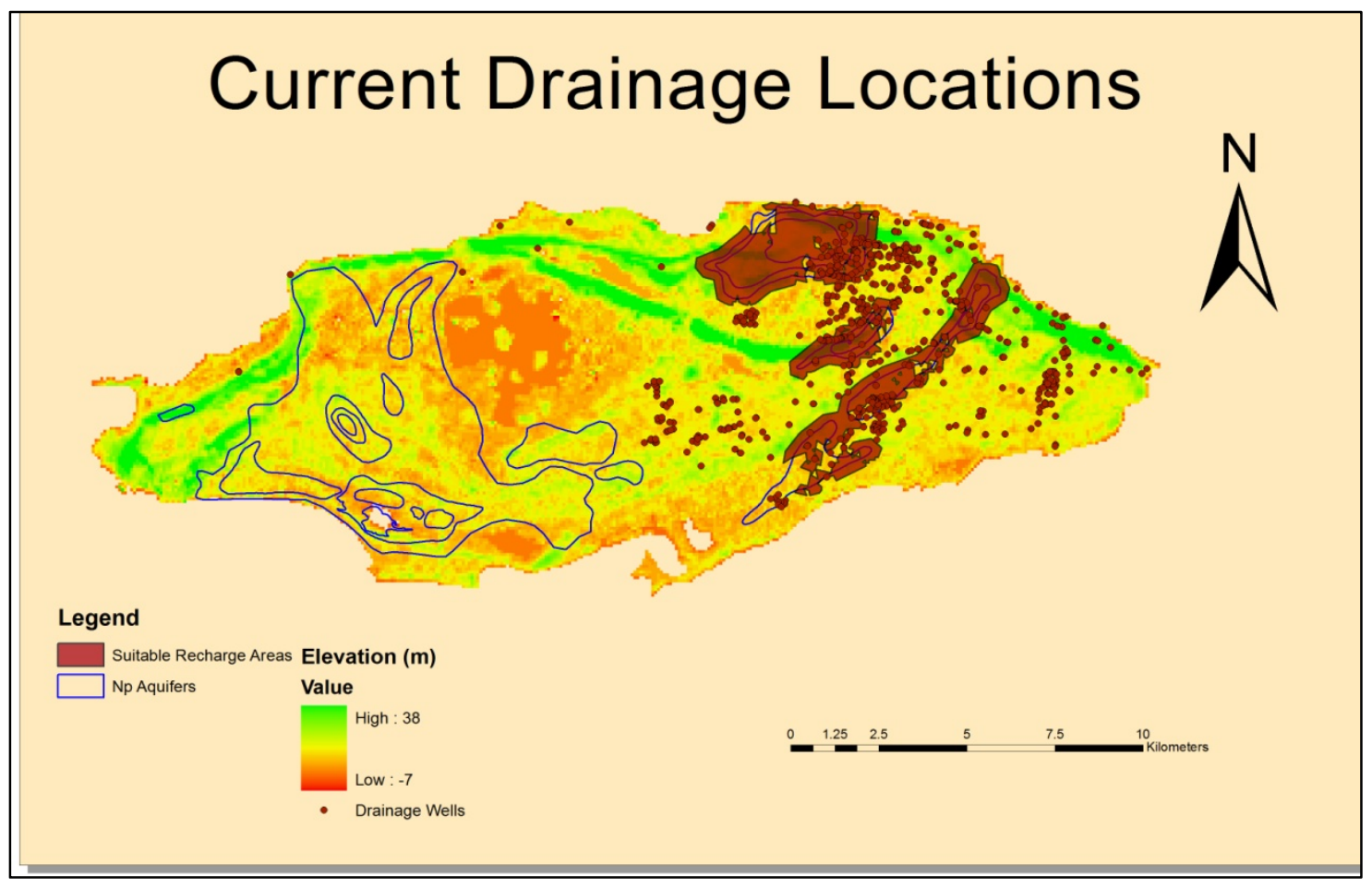

. Figure 5.3. Drainage wells in city of Nassau (Source: Ministry of Works and Transport, 2010) 


\subsection{CONCLUSIONS AND RECOMMENDATIONS}

This study has answered the questions posed at the outset concerning what factors in the hydrogeology of New Providence that will affect rainwater harvesting for recharge of aquifers, what areas will have most potential for recharge, and the amount of rainwater than may be available for recharge. On the basis of my findings, recommendations will be made for management of the resource represented by runoff as well as for future research.

\subsection{Conclusions}

Because of the rapid and generally unregulated development on New Providence, and especially in the capital city of Nassau, much of the surface has been transformed from being highly transmissive to highly impervious to the movement of water to the aquifers. This transformation has led to the creation of large quantities of surface runoff from roads, parking lots, and buildings and has drastically altered the natural water cycle of this island. My study has shown that the runoff from these impervious surfaces is substantial and, if captured in suitable locations, could be used to recharge the aquifers that are currently unusable and therefore return them to usefulness. According to the results from the GIS calculation, the quantity of runoff generated in the area designated as suitable for recharge totals $36,909,503 \mathrm{~m}^{3}$ per year based on rainfall averages from 1971 to 2000. Since it has been estimated that about twenty-five percent of rainfall eventually reaches the aquifers, we can make a conservative estimate that $17,95,038 \mathrm{~m}^{3}$ would actually be available for recharge, or $47,931 \mathrm{~m}^{3}$ per day. However, because the rainfall is unevenly distributed over the year, during the summer months the runoff depth 
will be higher and more water will be available. The challenge will be to find ways to capture this water and store it in spreading basins and wetlands for recharge to the aquifers.

It will require intervention by the government agencies involved to address this and there are obstacles that will have to be overcome in order to accomplish it. The intensity of development in the city of Nassau presents a major challenge as land for recharge is scarce. It will require the understanding and cooperation of the population along with drastic action of government to acquire land for recharge. It will require an investment of capital to reroute flows of water from the channels formed by roadways such as Blue Hill Road to areas designated for recharge. It will also require expertise in engineering to design and implement a system for this rerouting. However, because the quantity of water potentially available for recharge is vast and many benefits will accrue to the population from the increased natural freshwater, and to the government in savings of revenue, the effort and expense to carry out a plan to capture runoff for recharge of aquifers are well worth it.

Presently the water resources of New Providence are overseen by two agencies, each charged with separate responsibilities. Bahamas Water and Sewerage is concerned with delivering potable water to users by any means necessary. Therefore, much of the water used on the island is produced by desalination or by shipment from another island. As the cost of fuel continues to rise, production by desalination will become more expensive. Further, all nations may soon be faced with shortage of fossil fuels as the world's supply dwindles, and many nations are in the process of developing alternate fuel supplies. The Bahamas, as a small island developing state, does not have the resources to develop 
alternate fuel supplies and will have to continue to import fossil fuels for as long as it can afford to do so. In the meantime, the cost of producing fresh water by artificial means will continue to rise. The second agency involved with management of water, the Ministry of Works and Transportation, will continue its efforts to cope with flooding that will worsen as development continues and the residents will continue to bear the burden. There are a number of steps that may be taken to restore the damaged aquifers and alleviate flooding.

\subsection{Recommendations}

The Government of the Bahamas must develop a water management plan that will involve these two agencies as well as environmental health agencies and the public. This runoff water must be recognized as a valuable resource for all the residents and ways to capture and preserve it must be sought. A plan to capture the runoff will entail the procurement of land for the creation of spreading basins as well as a careful study of the flow patterns created by roadways and other impervious surfaces so that channels to direct that flow can be constructed. In the heavily developed areas this will be especially challenging as these areas are so densely populated, but it is precisely these densely populated areas that create most of the runoff.

The lack of zoning regulations has been a major contributing factor in the creation of the vast areas of impervious surfaces and this must be addressed. Any future development projects must be required to provide pervious areas to prevent the creation of more runoff and greater loss of water. Existing landholders should be given incentives 
for the creation of structures to capture rainfall. These incentives could be in the form of tax relief, rebates, or even direct payment.

Existing drainage wells should be inspected and suitability for their use as recharge wells should be determined. Those deemed suitable should be refitted with filters in order to deliver runoff to the aquifers and to prevent further pollution. No doubt many of the wells currently being used are contributing to pollution and a reversal of this by the addition of filters would aid in the recovery of those aquifers.

Even if artificial recharge of aquifers were accomplished, there would still be excess runoff water that would need to be managed. The excess water could be captured using other methods of rainwater harvest such as rooftop collection. Presently, Government does not encourage the public to harvest rainwater (see Appendix 1) although this would represent a large savings in the amount of freshwater that BWSC is providing to its customers. Water harvested by rooftop collection need not be used for drinking but could be a substitute for household use such as flushing toilets, washing clothes and automobiles, and watering lawns. A program should be started to give incentives to property owners to install rainwater collection systems on their buildings.

Finally, government must involve and educate the public to build awareness of the need for conservation and the benefits of artificial recharge. Only with the full understanding and cooperation of the population will any management plan succeed. Constructed wetlands and recharge areas need not be only utilitarian, but can add aesthetic value to a neighborhood as well. 


\subsection{Future research}

In order to successfully manage the runoff created by impervious surfaces on NP, further research is needed. A project must be implemented to map the flood plains created by the transformation of the surface to an impervious rather than transmissive type and of the channels created by roadways. The flow of water has been drastically altered by these surfaces and an understanding of the dynamics of runoff will be an aid in planning for future development as well as for corrective measures that may be needed for existing developments that experience severe flooding during heavy rainfall events. This will also be useful to demonstrate the problem and influence the attitude of the population. In addition, a study of the types and sources of pollutants that are being carried by the runoff from these surfaces should be done in order to raise public awareness of the necessity of taking action.

One of the limitations to this analysis was the age of the data. The landcover layer was digitized using maps originally drawn in the 1970s and the zoning map is almost a decade old. It will be necessary to reclassify the land use and landcover of New Providence in order to obtain more accurate results. It has been shown that remote sensing methods can be used successfully to map impervious urban areas (Melesse et.al., 2007; Braun \& Herold, 2003). I did not have the resources at my disposal to accurately classify the impervious areas but I was able to make a preliminary assessment that provided promising results and indicates that this method could be used effectively to update the existing data for New Providence. Using a Landsat image obtained from the Global Land Survey of the website, glovis.usgs.gov, an unsupervised classification was done using eight classes (Appendix 5). Three types of impervious areas were identified and runoff calculated on the total of these areas. A second 
assessment was made using the technique to derive fractional impervious surface from the scaled normalized vegetation difference index (NDVIs) as described by Melesse \& Wang (2007) (Appendix 6).

$F I S=1-\left[\frac{N D V I_{i}-N D V I_{\text {low }}}{N D V I_{\text {high }}-N D V I_{\text {low }}}\right]^{2}$

$\left(N D V I_{s}\right.$ range between 0 and 1$)$

where $\mathrm{NDVI}_{\mathrm{i}}$ is the NDVI value for pixel I, $N D V I_{\text {low }}$ and $N D V I_{\text {high }}$ are values for bare soil and dense vegetation, respectively (Melesse et. al., 2007). FIS shows the degree of imperviousness at a pixel level. FIS value of 1 shows 100 percent imperviousness for that pixel. By continuing the calculation of runoff with the weighted curve number method (Appendix 7), the results were obtained as shown in Table 5.1. Although this assessment is rudimentary, it illustrates the potential that exists for further development of this work and the possibility that the runoff resource is much greater than determined by this study.

Table6.1. Runoff volume results

\begin{tabular}{|l|l|}
\hline \multicolumn{2}{|c|}{ Runoff volume } \\
\hline Calculation & Volume ( $\mathbf{m}^{\mathbf{3}}$ ) \\
\hline GIS & $53,781,935$ \\
\hline Remote sensing-classified & $84,986,700$ \\
\hline Remote sensing-FIS & $116,456,800$ \\
\hline
\end{tabular}


This study has shown that there is a valuable resource on the island of New Providence in the form of fresh water from rainfall that is currently being wasted, which, with planning and careful management, can be captured and made available for the population now and in the future. 


\section{REFERENCES}

Asano, Takashi. Artificial Recharge of Groundwater. Stoneham, MA: Butterworth, 1985. Print.

Bahamas Handbook. Ed. Sylvia P. Dupuch. Etienne Dupuch Jr., 2010. 385-576. Print.

Bahamas Department of Meteorology. Bahamas Rainfall Statistics. Nassau 2008

Bahamas Department of Statistics. Census 2000. The Commonwealth of the Bahamas. statistics.bahamas.gov.bs (Accessed February 13, 2011).

Bahamas Environment, Science and Technology (BEST) Commission. The National Action Programme to Combat Land Degradation in the Bahamas. Nassau: BEST Commission, 2006. Print.

Bahamas Water and Sewerage Corporation (BWSC). Future Plans. Web. 6 Feb. 2011. $<$ http://www.wsc.com.bs/Futureplans.asp $>$.

Biswas, Himadri. "Numerical Groundwater Flow Modeling in the Wakal River Basin, India." Thesis. Florida International University, 2008. Print.

Bouwer, Herman. "Artificial recharge of groundwater: hydrogeology and engineering." Hydrogeology Journal 10.1 (2002): 121-42. Springer Berlin / Heidelberg. Web. 1 Aug. 2009. <http://www.springerlink.com/content/u0r3xtxnnfqm4p6y/>.

Bowen, Robert. Ground water. London: Applied Science, Halsted, 1980. Print.

Braun, Matthias and Martin Herold. "Mapping imperviousness using NDVI and linear spectral unmixing of ASTER data in the Cologne-Bonn region (Germany)" Proceedings of the SPIE 10th International Symposium on Remote Sensing, 8-12 September 2003, Barcelona, Spain

Brown, Chris J., Rebecca Weiss, Steve Sutterfield, Robert Verrastro, Peter Kwiatkowski, Steve Schubert, and Yvette Alger. "Development of an Aquifer, Storage and Recovery (ASR) Site Selection Suitability Index in Support of the Comprehensive Everglades Restoration Project." Http://www.evergladesplan.org/index.aspx. Comprehensive Everglades Restoration Project, 30 Nov. 2005. Web. 7 Dec. 2009.

Brown, Lester Russell. Plan B 2.0 rescuing a planet under stress and a civilization in trouble. New York, N.Y: W. W. Norton \& Company, 2006. Print.

Cant, Richard. Personal communication. 2009.

Cant, Richard V., and P. S. Weech. Water Resources Evaluation of the Bahamas. Tech. Nassau, Bahamas: Ministry of Works and Utilities, 1980. Print. 
Cant, Richard V., and Philip S. Weech. "A review of the factors affecting the development of Ghyben-Hertzberg lenses in The Bahamas." Journal of hydrology 84.3-4 (1986): 333-43. Print.

Carew, James L., and John E. Mylroie. "Geology of the Bahamas." Geology and Hydrogeology of Carbonate Islands. Ed. H. L. Vacher and T. M. Quinn. St. Louis: Elsevier, 1997. 91-139.

California Department of Water Resources. California Water Plan Update 2009. Volume 2, Chapter 25. Recharge Area Protection. http://www.waterplan.water.ca.gov/docs/cwpu2009/0310final/v2c25_rechgprotect _cwp2009.pdf.

Dagostino, Paul. "Water recharge project aids in Surprise growth (Surprise, AZ)." Pub: The Business Journal - Serving Phoenix \& the Valley of the Sun 13 Sept. 1996: $29+$.

Driessen, Paul. Lecture Notes on the Major Soils of the World. Rome: Food and Agriculture Organization of the United Nations, 2001. Web. 12 July 2010.

Einav, Rachel, Kobi Harussi, and Dan Perry. "The footprint of the desalination processes on the environment." Desalination 152 (2002): 141-54.

ESRI. ArcGIS Desktop 9.3 Functionality Matrix. Web. June 28, 2008 http://www.esri.com/library/brochures/pdfs/arcgis93-functionality-matrix.pdf

$\begin{array}{llllll}\text { ESRI. GIS for Water Resources. Web. } 2010 . & \end{array}$ http://www.esri.com/industries/water_resources/index.html

FAO. "Summary table: Renewable water resources in the world by country." Aquastat. Food and Agriculture Organization of the United Nations, 13 May 2003. Web. 15 Feb. 2009. <http://www.fao.org/nr/water/aquastat/water_res/waterres_tab.htm>.

Gale, Ian. "Strategies for Managed Aquifer Recharge (MAR) in semi-arid areas." IAH International Association of Hydrologists - The Worldwide Groundwater Organisation. International Association of Hydrologists, 15 Nov. 2005. Web. 9 Aug. 2009. <http://www.iah.org/recharge/>.

Ghayoumian, J., M.Mohseni Saravi, S. Feiznia, B. Nouri, and A. Malekian. "Application of GIS techniques to determine areas most suitable for artificial groundwater recharge in a coastal aquifer in southern Iran." Journal of Asian Earth Sciences 30 (2007): 364-74.

Hoffman, Steve. Planet Water: Investing in the World's Most Valuable Resource. Wiley, Hoboken. 2009. PDF. 
Izbicki, John A. "USGS - Seawater Intrusion in a Coastal California Aquifer." USGS California Water Science Center. Web. 05 Feb. 2011. $<$ http://ca.water.usgs.gov/archive/fact_sheets/b07/intro.html>.

Jothiprakash, V., G. Marimuthu, R. Muralidharan, and N. Senthilkumar. "Delineation of Potential Zones for Artificial Recharge Using GIS." Journal of the Indian Society of Remote Sensing 31.1 (2003): 37-47.

Melesse, A., and Wang, X., 2007. Impervious Surface Area Dynamics and Storm Runoff Response, Book Chapter in Remote Sensing of Impervious Surfaces, Ch. 19: 369384, CRC Press/Taylor \& Francis.

Melesse, Assefa M., Qihao Weng, Prasad S. Thenkabail, and Gabriel B. Senay. "Remote Sensing Sensors and Applications in Environmental Resources Mapping and Modeling." Sensors 7 (2007): 3209-241.

Millennium Ecosystem Assessment, 2005. Ecosystems and Human Well-being: Synthesis. Island Press, Washington, DC.

OAS. Source book of alternative technologies for freshwater augmentation in Latin America and the Caribbean. Washington: OAS, 1997.

O'Hare, M.P., Fairchild, D.M., Hajali, P.A., Canter, L.W., 1986. Artificial Recharge Of Groundwater.

Peters, Joseph H. Artificial Recharge Groundwater. Dallas: Taylor \& Francis, 1998.

Pyne, R. David G. Groundwater recharge and wells: a guide to aquifer storage recovery. Boca Raton: Lewis, 1995. Print.

Roebuck, Laura, Toni Ortiz, and Joy Pochatila. Water Resources Assessment of The Bahamas. Rep. US Army Corps of Engineers, 22 Nov. 2004. Web. 6 Feb. 2011. $<$ http://www.sam.usace.army.mil/en/wra/Bahamas/BAHAMASWRA.pdf $>$.

Rosegrant, Mark W., Ximing Cai, and Sarah A. Cline. World Water and Food to 2025 Dealing With Scarcity. Detroit: Intl Food Policy Research Inst, 2002. Http://www.ifpri.org/sites/default/files/publications/water2025.pdf. International Food Policy Research Institute, 24 Sept. 2003. Web. 30 Aug. 2009. $<$ http://www.ifpri.org $>$.

Sealey, Neil E. Bahamian Landscapes An Introduction to the Geography of the Bahamas. Grand Rapids: Media, 1995. Print.

Shiklomanov, Igor. "'World Fresh Water Resources"'" Water in Crisis: A Guide to the World's Fresh Water Resources. Ed. Peter H. Gleick. New York: Oxford UP, 1993. USGS Website. Web.

Stiefel, John M. "The Effectiveness of Rainwater Harvesting for Artificial Recharge of Groundwater." Thesis. Florida International University, 2007. 
Stormwater Solutions, Inc. (SSI) New Providence Island Stormwater Masterplan - Final Report. Rep. Unpublished, 2009.

Stuart, Kimberly M. "The Potential of Wind Energy for the Operation of Reverse Osmosis Water Plants in the Bahamas". Thesis. University of Nebraska. 2009.

Symposium. Artificial recharge of ground water proceedings of the International Symposium: Anaheim, California, August 23-27, 1988. New York, N.Y: ASCE, 1989.

Symposium. Artificial recharge of groundwater proceedings of the third International Symposium on Artificial Recharge of Groundwater: TISAR 98, Amsterdam, Netherlands, 21-25 September 1998. Rotterdam: A.A. Balkema, 1998.

U.S. Dept. of Agriculture (USDA), Soil Conservation Service, Engineering Division. CPESC, Inc. Urban Hydrology for Small Watersheds. [Washington, D.C.] 1986. $<$ http://www.cpesc.org/reference/tr55.pdf $>$.

United States Geological Survey (USGS) Global Visualization Viewer. http://glovis.usgs.gov

Wescoat, Jr, James L., and Gilbert F. White. Water for Life Water Management and Environmental Policy (Cambridge Studies in Environmental Policy). New York: Cambridge UP, 2003.

Whitaker, Fiona F., and Peter L. Smart. "Hydrogeology of the Bahamian Archipelago." Geology and Hydrogeology of Carbonate Islands. Ed. H. L. Vacher and T. M. Quinn. St. Louis: Elsevier, 2004. 183-216. 


\section{APPENDICES}

Appendix 1. TR-55 lookup table for urban areas (USDA, 1986)

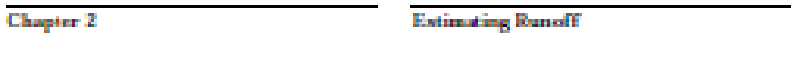

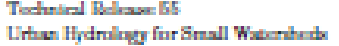

Table 2-2a Fonoff carvenumbers for urtan areas 1

\begin{tabular}{|c|c|c|c|c|c|}
\hline \multirow[b]{2}{*}{ Cwer type and tydrologe eondtion } & \multirow{2}{*}{$\begin{array}{l}\text { Averupe percont } \\
\text { impervious areaz }\end{array}$} & \multicolumn{4}{|c|}{$\begin{array}{l}\text { Curve numbers for } \\
\text { - trydrologie sool group. }\end{array}$} \\
\hline & & $\mathbf{A}$ & B & c & D \\
\hline
\end{tabular}

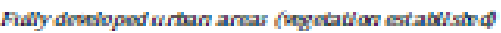

Openspace (lawns, parks, golr eourves, exmeteries, cte) Poor eondinon (graw eover < BOA6) -

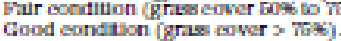

Impentous arcses:

ed parking locs, roots, dr

strocts and roest

Pawst cartes and stom scwon (cesclualng

right-ot-way)

right-ol-way) -..................

Paved open diluches inchuding rigtt-o(-way)

Dirt (probaling right-if-way)

Westarn desert urtesi aneas:

Nitural desert landsecapting (pervious arcas oely) $y$

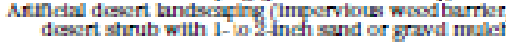
and heein bonders?

Urtau destricts:

Commerest and bustness

Infustrial

Pesidential distriess by avernge lot stax:

$1 / 5$ ane or less (town holves')...

$1 / 4$ ance

$1 / 2$ ance

$1 / 2$ ance

1 aure
2 aurs

B

Devegongunarion and

Newhy grated ances

(pernious areas only, no regetacion)-1'

$\begin{array}{llll}68 & 79 & 88 & 89 \\ 49 & 69 & 79 & 84 \\ 39 & 61 & 74 & 89\end{array}$

le lants (CN) are determined using eover types stinllar to thoee in table 2:3e)

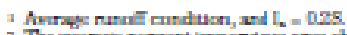

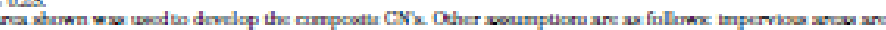

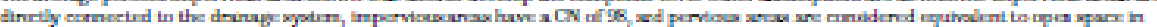

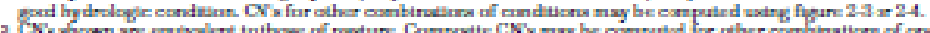

covertype

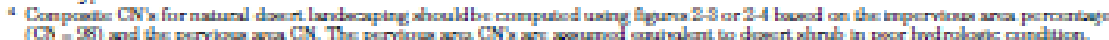

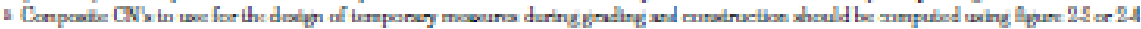

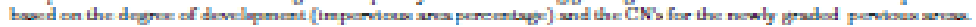


Appendix 2. TR-55 chart for selecting curve numbers (USDA, 1986)

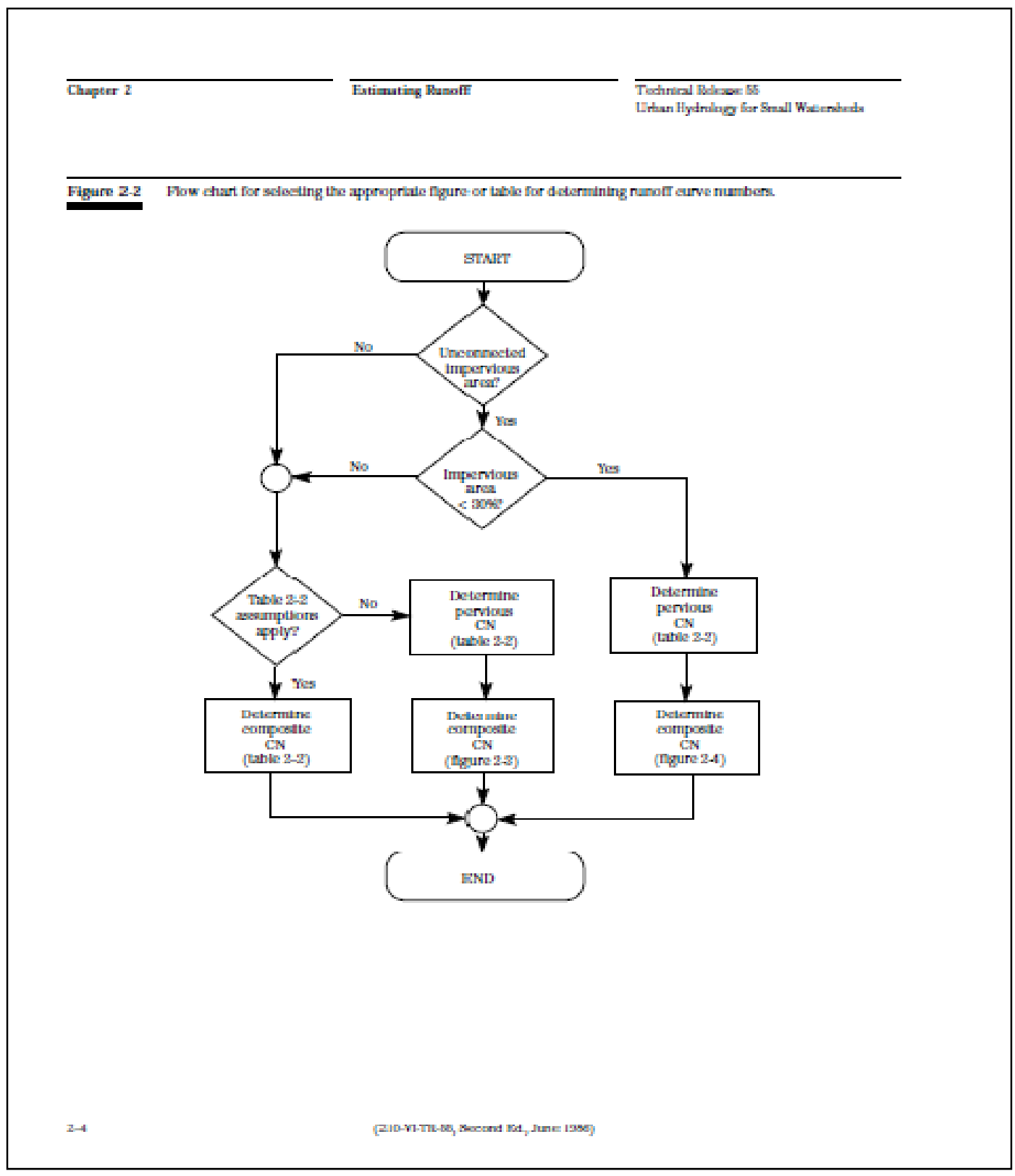


Appendix 3. Worksheet 2 from TR-55 manual (USDA, 1986)

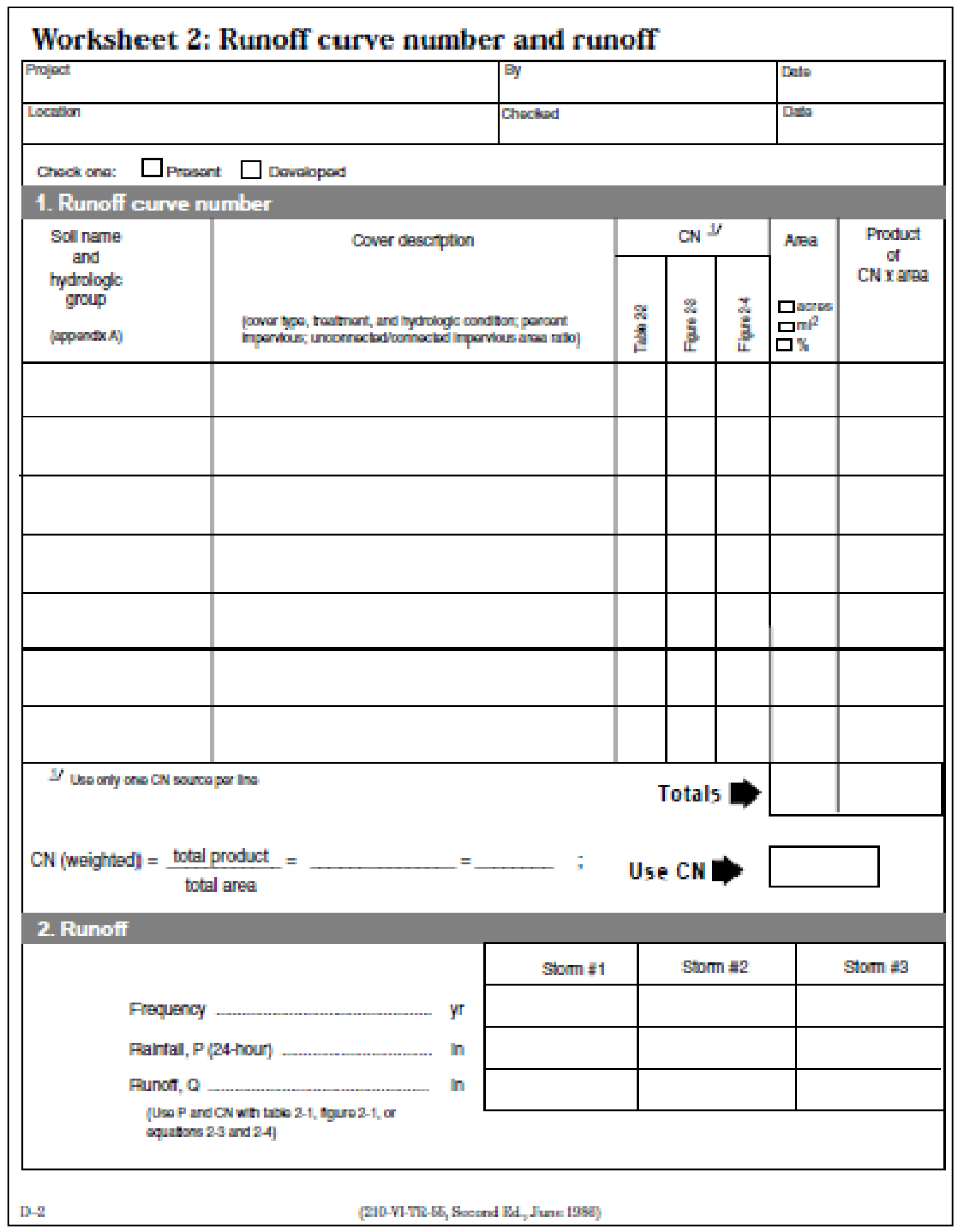




\section{Appendix 4. Summary of Bahamas Government Cabinet Paper on proposal for mandatory use of rainwater tanks.}

There are a wide range of effects that would result from the mandatory use of rainwater tanks; these can be classified under
the following:

1. Conservation

2. Health

3. Economics

4. Legislation

5. Practical Considerations

1. CONSERVATION

Collecting and storing rainwatex is more efficient than retrieving it from tho ground - about $75 \%$ of rainfall is be recovered from a froshwater lems.

2. HEALTH

Stored water is liablo to contamination, from a variety of sources, and therefore, it is advisable that water from a tank be used for non-potable purposes only. This tends to defeat the purpose of the proposed legislation. If rainwater tanks are to be used for potable purposes then a government out such a safeguard tho rainuater these supplies aro safe. Withing and irxigation.
ing a the ranwater can only be uscd for flush-

3. ECONOMICS

(a) Forcing the public to build rainwater tanks increases the cost of housing significantly, and particularly so in the case of low cost housing. Estimates of the increase in building costs range from $10 \%$ to $30 \%$ depending upon the house and the size of storage needed. The 30\% increase would apply to low cost housing.

(b) If everyone is forced to install the infrastructure needed to make use of their rainwater, then there will be a significant increase in such imports as pumps. pressurized tanks, and pipework etc. To invest this money in water supply it would be better if it were channeled directly to the Water and Sewerage corporation instead.

(c) The water \& Sewerage Corporation obtains no benefit from rainwater catchment because the tanks are most effective in the rainy season which is when there is little problem in meeting demand. At the same time the corporation would demand. At the same time structure and personnel that is needed the infrastructure and personnel that is needed to raeet the full demand because tho tanks are liable to dry up after a long drought. Because rainfall is erratic the corporation would never be able to assess what future demands may be or make provisions to meet them It would be impossible to predict what revenues would be expocted from the sale of water. 
(d) Home owners would expect to recover the money spent on the construction of the rainwater tank from reduced water bills, but, becalse sales would be reduced, though potential demand stays just as high, then watbr rates would have to be increased to cover corporation expenses.

\section{LEGISLATION}

If rainwater tanks become mandatory it would be necessary to amend the Building Code as well as water Rules 3 and I. which deal with independent water supplies for water closets and storage cisterns, respcctively. Irrespective of benefits, enforced conservation is usually unpopular.

\section{PRACTICAL CONSIDERATIONS}

(a) Because of the health fuctor each house would have to have dual pipework to ensure that there is no chance of a cross-connection with the city supply.

(b) Because there is no relationship between the size of a house and the number of people in it, or, in effect its water demand, a variety of arbitrary decisions would be needed to decide on the size of storage tank required and in some instances this would be unfair.

(c) In some places rainwater tanks would be easier and cheaper to build than in others, for example a high water table can present difficulties.

(d) The legislation would have to apply to New Providence only because very few other islands with any signiEicant population are short of water resources.

(e) Wealthy home owners arc already utilizingrainwater tanks, on a large scale, particularly in areas where groundwator is saline. Because of this the new law would have its strongest impact on the poorer classes, which is undersirable.

\section{CONCLUSION}

Only item 1 supports the mandatory use of rainwater tanks. 
Appendix 5. Unsupervised classification of landcover using remote sensing.

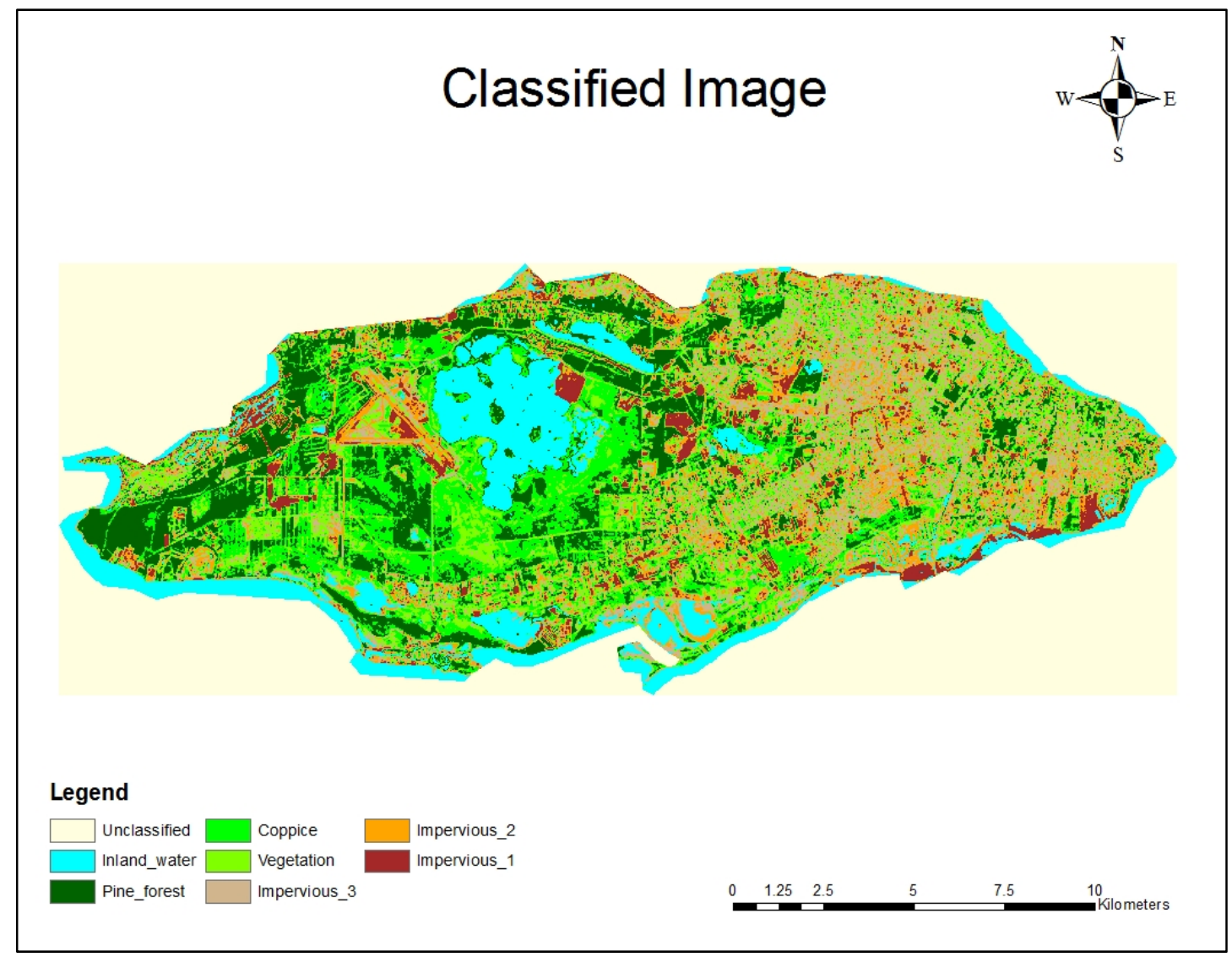


Appendix 6. Calculation of fractional impervious surface: $0=$ non-impervious; $1=$ impervious.

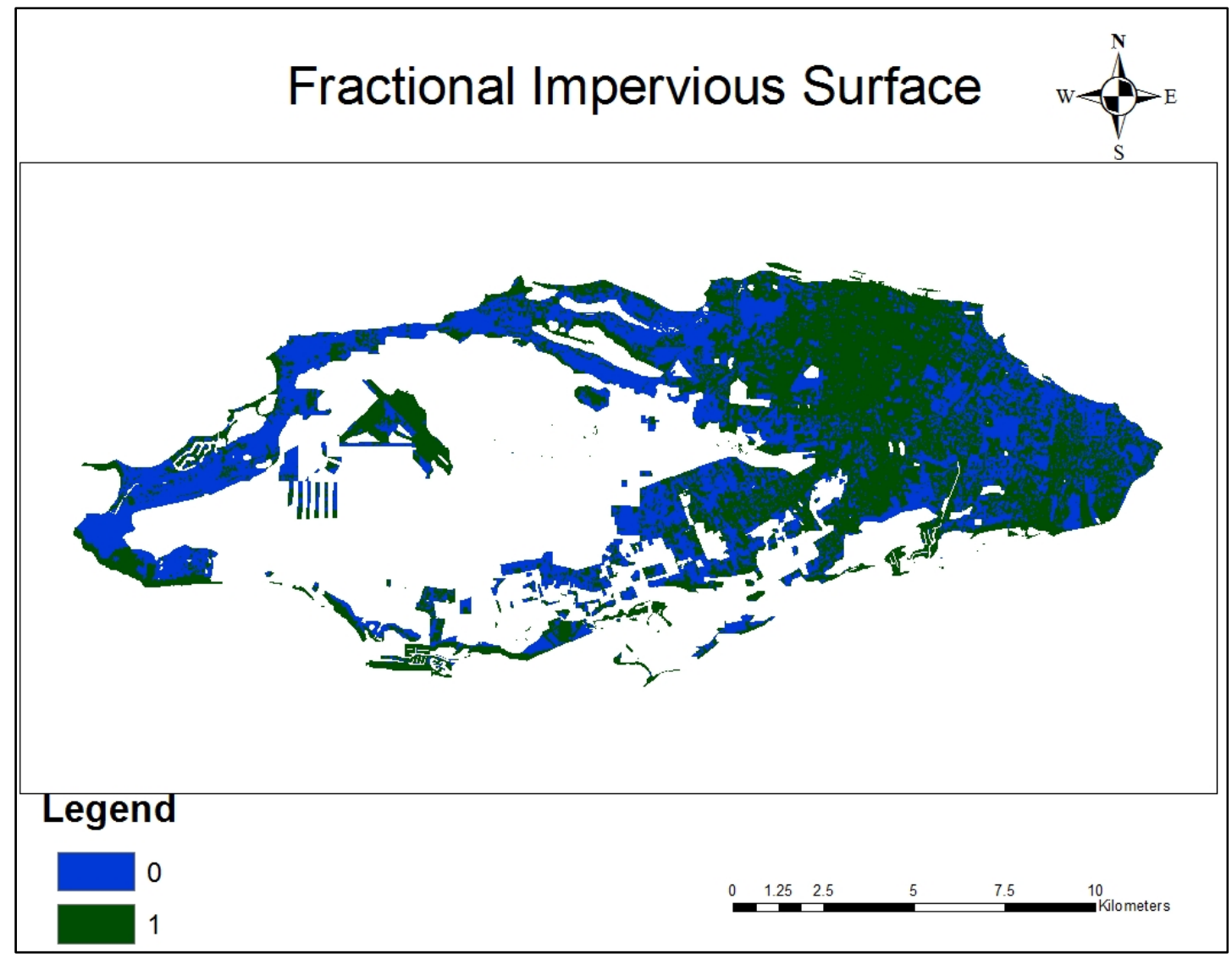


Appendix 7. Weighted curve number for all impervious surfaces

\begin{tabular}{|l|r|r|r|}
\hline \multicolumn{3}{|c|}{ Weighted Curve Number } \\
\hline Zoning & Area & CN & Area x CN \\
\hline SF 1/8 ac. & $2,710,699.64$ & 77 & $208,723,872.04$ \\
\hline SF 1/4 ac. & $9,196,262.61$ & 61 & $560,972,019.09$ \\
\hline SF 1/3 ac. & $5,362,566.10$ & 57 & $305,666,267.92$ \\
\hline SF 1/2 ac. & $705,825.10$ & 54 & $38,114,555.35$ \\
\hline Multi-Family M.F. & $2,649,443.93$ & 81 & $214,604,957.97$ \\
\hline Duplex D. & $2,958,186.03$ & 77 & $227,780,324.01$ \\
\hline Multi-Unit M.U. & $7,038,337.73$ & 81 & $570,105,355.73$ \\
\hline Townhouse T. & $1,122,801.89$ & 89 & $99,929,368.23$ \\
\hline Commercial and business C. & $4,969,635.05$ & 89 & $442,297,519.39$ \\
\hline Paved roads (weighted CN) & $7,487,747.82$ & 87 & $651,434,060.64$ \\
\hline Institutional Public & $236,111.38$ & 81 & $19,125,021.71$ \\
\hline Institutional Government & $1,238,815.50$ & 81 & $100,344,055.33$ \\
\hline Industrial & $114,881.50$ & 81 & $9,305,401.34$ \\
\hline & & & \\
\hline Weighted & $\mathbf{4 5 , 7 9 1 , 3 1 4 . 2 6}$ & $\mathbf{7 5}$ & $\mathbf{3 , 4 4 8 , 4 0 2 , 7 7 8 . 7 4}$ \\
\hline
\end{tabular}

